\title{
Shallow sampling by multi-shot laser ablation and its application within U-Pb zircon geochronology
}

Eoghan P. Corbett*a,b,1, Antonio Simonetti ${ }^{\mathrm{a}}$, Phil Shaw ${ }^{\mathrm{c}}$, Loretta Corcoran ${ }^{\mathrm{a}}$, Quentin G. Crowley ${ }^{\mathrm{b}}$, Brendan C. Hoare ${ }^{\mathrm{b}}$.

${ }^{a}$ Department of Civil and Environmental Engineering and Earth Sciences (CEEES), University of Notre Dame, IN 46556, USA

bepartment of Geology, Trinity College Dublin, Dublin 2, Ireland.

'Nu Instruments Ametek, Wrexham LL13 9XS, Wales, UK.

${ }^{*}$ Corresponding author. Email address: corbetep@tcd.ie

${ }^{1}$ Present address: Department of Geology, Trinity College Dublin, Dublin 2, Ireland.

\begin{abstract}
The interaction of incident laser radiation and sample substrate is complex and difficult to predict. Natural zircons are often both structurally and chemically heterogeneous in 3-dimensional space. Encountering growth-related, structural micro-heterogeneities, inclusions and chemical complexities is almost inevitable during a static ablation of several tens of seconds. A multi-shot approach to laser ablation described here implements a minimal sample exposure time to incident laser radiation by applying multiple $1 \mathrm{~Hz}$ shots to a single sample location in delayed succession. This process can be conceptualised as a "slowing down" of a high-frequency $(5-20 \mathrm{~Hz})$ static laser ablation inductively coupled plasma mass spectrometry (LA-ICP-MS) analysis until each laser pulse is distinct albeit transient. The ability to integrate and collate signal pulses for a small number of consecutive laser shots, as opposed to continuously pulsing the laser, produces precise age determinations ( $1 \%$ reproducibility, $2 \sigma$ level) on small sample volumes (704 $\pm 23 \mu \mathrm{m} 3$ on 91500 zircon standard). The multi-shot LA-ICP-MS protocol employed here significantly reduces the effect of 'downhole' fractionation as the resultant craters are extremely shallow (as shallow as $0.56 \pm 0.02$ $\mu \mathrm{m}$ on 91500 zircon standard) and maintain an aspect ratio of $\ll 1$. Further benefits include a reduced probability of thermally induced effects (e.g., substrate melting), plasma loading, and the potential for signal mixing (with depth) in a heterogeneous sample.
\end{abstract}

Keywords: Low sample volume; Multi-shot LA-ICP-MS; Sub-micron sampling; Depth resolution; Downhole fractionation; LIEF

\section{Introduction}

Zircon U-Pb ages determined by the benchmark isotope dilution ther- mal ionization mass spectrometry (ID-TIMS) method, are often system- atically at variance $(1-2 \%, 2 \sigma)$ to those determined by in-situ laser ab- lation-inductively coupled plasma mass spectrometry (LA-ICP-MS) for the same sample set (Horstwood et al., 2016; Košler et al., 2013). Despite rapid advances in LA-ICP-MS instrumentation, techniques, pre-treatments and a converging consensus on how zircon $\mathrm{U}-\mathrm{Pb}$ data-reduction protocols are to be employed (e.g., Horstwood et al., 2016), laser induced elemental fractionation (LIEF) arguably still remains the single greatest obstacle in achieving the analytical precision and accu- racy associated with other, often more costly in-situ techniques (e.g., secondary ion mass spectrometry, SIMS; Chew et al., 2018)

Non-stoichiometric sampling of the target analyte due to LIEF has often been reported for high-frequency, static ablation protocols used extensively in U-Pb geochronological studies (e.g., Fryer et al., 1995; Hirata and Nesbitt, 1995; Longerich 
et al., 1996; Horn et al., 2000; Kuhn et al. 2003). Laser operational parameters directly affect the properties of laser-generated aerosols, particle-size distribu- tion, dehydration, atomization and ionization ef ciency, and hence di- rectly in uence the degree of fractionation occurring within the system (Bleiner and Günther, 2001; Guillong and Günther, 2002; Koch et al., 2002; Horn and Günther, 2003; Kuhn et al., 2004).

Various studies demonstrate a minimisation of LIEF by utilizing a short (157 or $193 \mathrm{~nm}$ ) laser wavelength (e.g., Russo et al., 2000; Jackson et al., 2004; Kroslakova and Günther, 2007), maintaining focus above the material surface (Marillo-Sialer et al., 2014; Liu et al., 2000), careful adjustment of carrier gas flow and composition (Günther and Heinrich, 1999; Horn and Günther, 2003; Kroslakova and Günther, 2007), and avoiding melting or particle re-deposition over the sample surface by utilizing shorter pulse widths (Eggins et al., 1998; ; Shaheen et al., 2012). The most practicable means by which LIEF can be minimised however, is by ensuring craters are of a critical aspect ratio (depth/diameter) <1 (Mank and Mason, 1999, 2001).

For zircon, a high affinity of $\mathrm{U}$ (and $\mathrm{Hf}$ ) for $\mathrm{Zr}$ results in its retention within the crater during a laser induced phase transition of $\mathrm{SiO}^{2}$ to $\mathrm{ZrO}^{2}$ (Kuhn et al., 2009). Both Si and $\mathrm{Pb}$ show no such a nity and freely are mobilised out of ablation craters as condensate independently of their diameter (Košler et al., 2005, Kuhn et al., 2009). U reten- tion during ablation was shown by Kuhn et al. (2009) to be crater-size dependent. Where an aspect ratio can be kept $\ll 1$, LIEF of this kind can be reduced well within the associated analytical uncertainty, eliminating the need to propagate any additional uncertainty (Horstwood, 2008).

Authors of similar, previous work to that presented here (e.g., Cottle et al., 2009, 2012) demonstrated the utility and potential of a single-shot approach to laser ablation for minimising sample destruction and improving depth resolution, by integrating discrete peaks generated by consecutive single laser pulses. The analytical procedure presented in this contribution differs from these previous works insofar as shot-to-shot resolution is not the primary concern. A complete and ultra-fast washout of the analyte (and the associated small-volume ablation cell) is consequently not required. Instead, the relatively large volume of the standard ablation cell $(\sim 8 \mathrm{~cm} 3)$ is utilised in concert with a short washout duration ( $3 \mathrm{~s})$ to maintain an elevated signal through- out an analysis, with only a partial washout between laser pulses. Hence fewer shots need be applied to the sample surface, as isotope ratio de- termination can be made for each $1 \mathrm{~Hz}$ laser shot. Herein lies the ad- vantage of a multi-shot approach to laser ablation; the resulting depth achieved after either 30 or 10 shots is much shallower than a conventional laser analysis (e.g., up to $96.5 \%$ shallower than some other ablation protocols (Horstwood, 2008), and demonstrably minimises U-Pb 'downhole' fractionation. The approach to laser ablation analysis de- scribed here may help to overcome other sources of laser induced elemental fractionation (LIEF) such as, thermally induced effects (e.g., substrate melting), plasma loading effects and crucially, intra-crystalline signal mixing (with depth).

The analytical protocol reported here routinely produces weighted mean age determinations largely reproducible to $\leq 1 \%(2 \sigma)$ on small sample volumes (as low as $704 \pm 23 \mu \mathrm{m} 3$ ) with a $40 \mu \mathrm{m}$ diameter spot, demonstrating an overall improvement in internal precision over that of a single-shot approach alone (Cottle et al., 2009). The multi-shot method outlined here is validated with results obtained on zircon standard reference materials and samples dated using benchmark ID-TIMS. 


\section{Materials and methods}

\subsection{Instrumentation}

Ablations were performed using a UP-213 frequency quintupled deep UV $(\lambda=213 \mathrm{~nm})$ solid-state Nd:YAG laser ablation sampling system (New Wave Research, USA). This was coupled to a Nu Attom High Resolution (HR)-ICP-MS instrument (Nu Instruments, UK), at the Midwest Isotope and Trace Element Research Analytical Center (MITERAC), University of Notre Dame, USA. Analytical set-up and operating parameters are summarised in Table 1. The sweep gas flow rates and temperatures within spray chamber and desolvating membrane were monitored and maintained with a Aridus II Desolvating Nebulising system (CETAC Technologies, USA). The sweep gas flow rate proved particularly influential in the resultant reproducibility of $\mathrm{U} / \mathrm{Pb}$ ratios, given the small volumes of analyte being sampled. Ideal laser and sweep gas set-up and parameters were 'dialled in' over the course of multiple analytical sessions by monitoring reproducibility on measured $\mathrm{U} / \mathrm{Pb}$ ratios of NIST612 standard glass. The $\mathrm{Nu}$ Attom HR-ICP-MS instrument was operated in low resolution, peak jump detector mode during a time-resolved analysis (TRA). In this mode, the magnet position is static or 'parked' at a mass of interest (i.e., 206) in the middle of the Pb-isotope range. The detector plate voltages can therefore achieve very fast and reliable scanning or peak jumping over the narrow mass range set by the operator, in this instance between masses 202 and 238. The fastscan ion optics facility of the Nu Attom allows for a maximal acquisition time at the top of each mass peak de ned by the user in the TRA analysis le during a sweep. The TRA used herein to derive ages operated at differing sweep and cy- cle settings depending on the shot count used. Dwell times were fixed at $500 \mu$ s on each mass of interest, namely; 202, 204, 206, 207, 208, 235 and 238. Magnet calibration and detector tuning were conducted prior to TRA by aspirating a tune solution containing $0.5 \mathrm{ppb} \mathrm{U}$ and $\mathrm{Pb}$ in dry plasma mode. A subsequent, secondary check of the tune conditions was carried out in-situ on NIST612 standard glass by laser ablation after He was introduced into the system $\left(1 \mathrm{Lmin}^{-1}\right)$. The working values used for NIST612 are from Woodhead and Hergt (2001). Crater depth determinations and imaging were made using a Profilm3D (Filmetrics, USA) White Light Interferometer (WLI) and a TESCAN TIGER MIRA3 variable pressure field emission scanning electron microscope (FE-SEM) equipped with a secondary electron detector at the iCRAG lab, Trinity College Dublin, respectively. The WLI technique optically measures surface roughness and texture, allowing a three-dimensional visualization and quantitative measurement of ablation crater depth and geometry to a vertical resolution of $0.176 \mu \mathrm{m}$. The cross-sectional depth of each crater was derived from five different linear transect measurements, conducted in differing orientations. The representative depth of an individual crater is given by the mean of these separate measurements $(n=5)$ and its associated uncertainty is derived from the range in measured values. A total of 20 craters were measured in this manner for every sample analysed to determine the mean resultant depth for a sample set. The uncertainty associated with these values was propagated by quadrature.

\section{Laboratory and Sample Mount Preparation}

Laboratory name(s)

Sample type/mineral
Midwest Isotope and Trace Element Research Analytical Center (MITERAC), University of Notre Dame, USA; iCRAG lab, Trinity College Dublin, Ireland. 
Sample preparation

Conventional mineral separation where appropriate, $25 \mathrm{~mm}$ round resin mount, polished to $1 / 4 \mu \mathrm{m}$ finish

Laser ablation system

\begin{tabular}{ll}
\hline Make, Model and type & ESI/New Wave Research, UP-213 solid stat \\
Wavelength $(\lambda)$ & $213 \mathrm{~nm}$ \\
Pulse width & $3 \mathrm{~ns}$ \\
Fluence & $\sim 3 \mathrm{Jcm}^{-2}$ \\
Repetition rate & $1 \mathrm{~Hz}$ \\
Spot size & $40 \mu \mathrm{m}$ \\
Shot count & 10 or 30 \\
Sampling mode/pattern & Sequential single shot, static spot ablation \\
Washout interval & $3 \mathrm{~s}$
\end{tabular}

Transport regime and sweep gas flow

\begin{tabular}{|c|c|}
\hline Laser cell volume & standard 'quick-change drawer' cell $\left(\sim 8 \mathrm{~cm}^{3}\right)$ \\
\hline Transport tubing dimension & $200 \mathrm{~cm} \times 0.48 \mathrm{~cm}(\mathrm{ID})$ of Teflon lined Tygon $®$ tubing \\
\hline $\begin{array}{l}\text { Cell atmosphere and transport gas } \\
\text { composition }\end{array}$ & $\begin{array}{l}100 \% \mathrm{He} \text { in cell, Ar auxiliary gas combined via ' } Y \text { '-style } \\
\text { connection } 20 \mathrm{~cm} \text { before entry into the ICP source }\end{array}$ \\
\hline Sweep gas flow & $1 \mathrm{Lmin}^{-1}(\mathrm{He})$ \\
\hline Auxiliary gas flow & $\begin{array}{l}3 \mathrm{Lmin}^{-1}(\mathrm{Ar}) \text { at } 110^{\circ} \mathrm{C} \text {, maintained by a CETAC Aridus II } \\
\text { desolvating nebuliser, Nebuliser pressure } 27.8 \mathrm{psi}\end{array}$ \\
\hline \multicolumn{2}{|l|}{ ICP-MS Instrument } \\
\hline Make, Model and type & $\begin{array}{l}\text { Nu Instruments, Nu Attom HR-ICP-MS, magnetic sector single } \\
\text { collector }\end{array}$ \\
\hline Detector mode & $\begin{array}{l}\text { Static/parked magnet, peak jump detector mode, combined with } \\
\text { FastScan lon optics }\end{array}$ \\
\hline Forward RF power & $1300 \mathrm{~W}$ \\
\hline Reflected power & $\leq 3 \mathrm{~W}$ \\
\hline Sweeps & 10 \\
\hline Cycles & 2500 (for a 10 shot analysis) or 10000 (for a 30 shot analysis) \\
\hline Dwell time & $500 \mu s$ on each isotope \\
\hline Measured masses & $202,204,206,207,208,235,238$ \\
\hline
\end{tabular}

\section{Data Processing}

\begin{tabular}{ll}
\hline Gas blank/Baseline duration & Minimum $30 \mathrm{~s}$ \\
Calibration strategy & 91500 was used as primary reference standard in brackets of \\
& $n=5$ either side of validation samples $(n=10)$, except when \\
& Plešovice was used.
\end{tabular}


Data processing and plotting package(s)

Common-Pb correction

LIEF correction

Uncertainty level and propagation
Python based script add-ons operating within Nu Instruments, Nu Quant software platform; in-house Microsoft Excel( spreadsheet; IsoplotR online (Vermeesch, 2018)

No common-Pb correction applied

No LIEF correction applied

Ages herein are quoted at $2 \sigma$ absolute, uncertainty propagation is by quadratic addition.

Table 1. Instrument set-up and operational parameters

\subsection{Pre-treatment and sample preparation}

Thermal pre-treatment by annealing was conducted on a sub-set of samples (summarised in Table 2), to investigate the effect heat-treatment on resultant crater morphologies. Samples were heat-treated at either $850{ }^{\circ} \mathrm{C}$ for $48 \mathrm{~h}$, or at $1100{ }^{\circ} \mathrm{C}$ for $96 \mathrm{~h}$ (Mattinson, 2005; Nasdala et al., 2006). Where a heat-treated sample was being analysed, a primary reference having received the same heat-treatment was used as an external standard.

\begin{tabular}{lll}
\multicolumn{1}{c}{ Sample Name* } & Pre-treatment & \multicolumn{1}{c}{ Reference material information } \\
\hline $91500(\mathrm{U})$ & Untreated & 91500 (Wiedenbeck et al., 1995) \\
$91500(850 / 48)$ & $850^{\circ} \mathrm{C}$ for $48 \mathrm{~h}$ & \\
$91500(1100 / 96)$ & $1100^{\circ} \mathrm{C}$ for $96 \mathrm{~h}$ & \\
\hline Plešovice (U) & Untreated & Plešovice (Sláma et al., 2008) \\
Plešovice (850/48) & $850^{\circ} \mathrm{C}$ for $48 \mathrm{~h}$ & \\
Plešovice (1100/96) & $1100^{\circ} \mathrm{C}$ for $96 \mathrm{~h}$ & \\
\hline DD85-17 (U) & Untreated & DD85-17 Mafic Tonalite, Marmion batholith (Tomlinson \\
DD85-17 (850/48) & $850^{\circ} \mathrm{C}$ for $48 \mathrm{~h}$ & et al., 2003) \\
DD85-17 (1100/96) & $1100^{\circ} \mathrm{C}$ for $96 \mathrm{~h}$ & \\
\hline DD81-29 (U) & Untreated & DD81-29 Heronry Lake Diorite Intrusion (Davis \& \\
DD81-29 (850/48) & $850^{\circ} \mathrm{C}$ for 48 h & Edwards, 1986) \\
DD81-29 (1100/96) & $1100^{\circ} \mathrm{C}$ for 96 h & \\
\hline WRS-1348 (U) & Untreated & WRS-1348 (Pointon et al., 2012) \\
\hline Fish Canyon Tuff (U) & Untreated & Fish Canyon Tu Zircon (Bachmann et al., 2007) \\
& & \\
\hline
\end{tabular}

Table 2. Sample names, ages and pre-treatment descriptions for each of the studied samples. *Annealed sets of a given sample are labelled with an $(850 / 48)$ or $(1100 / 96)$ suffix pursuant to the treatment they received (e.g., DD85-17 (850/48) was heat treated at $850^{\circ} \mathrm{C}$ for $\left.48 \mathrm{~h}\right)$. Untreated samples are labelled with a $(U)$ suffix.

Regardless of whether a thermal pre-treatment was conducted, it is necessary to ensure all sample surfaces are as clean as possible prior to analysis. Surface contamination (i.e., common- $\mathrm{Pb}$ ) is a concern when sampling such low volumes of material. All samples were subject to several rounds of sonication and rinsing prior to being mounted in a two-part epoxy resin mount. After mounting and polishing, the mount was subject to a further round of cleaning, which involved; (1) several seconds rinsing with ethanol, (2) sonication in a sealed, ethanol filled vessel for $30 \mathrm{~min}$, (3) rinsing with high-purity water, (4) sonication in sealed, high-purity water filled vessels for $30 \mathrm{~min}$, (5) further rinsing with high-purity water, and (6) dried using electronicssafe, pressurised air. Similar care was taken to clean the ablation cell prior to the start of each analytical session. 


\subsection{Analytical procedure and timeline}

All analytical sessions were structured with a sample-standard-bracket technique consisting of five primary reference standard analyses on either side of 10 validation sample analyses (treated as "unknown"), until a total of 20 "unknown" analyses were conducted (i.e., 5-10-5-10-5). Each sample received a total of either 10 or 30 single-shots in sequence before moving onto the next location/sample. Where possible, laser spots were placed in order to avoid any cracks or inclusions visible on the sample surface.

During a TRA, a baseline determination was made for up to $30 \mathrm{~s}$ prior to opening the laser shutter. During this time interval, the laser is continually red at a repetition rate of $4 \mathrm{~Hz}$ against the laser shutter, to thermally stabilise or 'warm up' the laser head. The laser shutter opens for $1 \mathrm{~s}$ to allow a single $(1 \mathrm{~Hz})$ shot to strike the focussed sample surface, a $3 \mathrm{~s}$ washout interval then follows allowing a partial return to baseline of the signal before the next laser shot. This partial return towards baseline is crucial as it maintains an elevated signal intensity whilst also allowing the NICE script Nu-Quant software add-on to decipher signal peaks. This cycle of firing and washout con- tinues until either 10 or 30 consecutive laser shots have been red in the same location. The duration of a multi-shot analysis conducted in this manner is $\sim 3$ to 8 min depending on the total shot count applied. A standard bracketed analytical session consisting of several such multi-shot analyses $(n=35)$ therefore, can take up to between 2 and $5 \mathrm{~h}$. It should be noted that no pre-ablation shot or raster procedure was undertaken in this study to 'clean' the sample of potential surface common $\mathrm{Pb}$ contamination, as the $204 \mathrm{~Pb}$ ion signal remained below the limit of quantification (LOQ) throughout each analysis. As a precautionary measure the first $10 \%$ of shots are ignored within the Nu Quant software to avoid any potential for 204Pb surficial contamination, but can still be integrated as part of the TRA at the user's discretion.

\subsection{Signal integration and data reduction}

Nu Quant is Nu Instruments software developed for processing data obtained using the Attom HR-ICP-MS. It allows the user to construct batch files containing several separate TRA les. Single and multi-shot analyses require each TRA to be processed using a NICE script add-on, which operates within the Nu Quant software platform. The Nu Quant software platform offers the freedom for users to construct and import their own Python-based NICE scripts for data reduction purposes. Two NICE script variants were developed for the purposes of multi-shot data reduction; version 2 (v.2), which utilises user de ned $238 \mathrm{U}$ signal threshold values to determine the start and end of each laser shot; and version 5 (v.5), whereby the software delineates signal pulses between the start of the signal for the first shot and the end of the signal for the final shot. Both require the user to input multiple parameters before the signals can be compiled. These iterations of the script contained the most robust algorithms tested within this study and are freely available as supplementary material.

\subsubsection{Version 2 ( $v .2)$}

The start and end points of the 30s baseline/'gas-blank' measurement (acquired prior to ring the laser) are defined by the user in terms of "baseline start cycle" and "baseline end cycle", respectively. This selection of baseline continuum signal is used to subsequently perform a baseline subtraction calculation of the net acquired signal intensities. Ideally therefore, users should select as much of a representative baseline signal as possible. The user must also determine the "start peak trigger", a threshold 
value for the $238 \mathrm{U}$ ion signal, which will de ne the start and end points of signal peaks. To avoid falsely triggering and integrating signal peaks too narrow to be real (i.e., signal noise), the user defines the minimum channel width, which constitutes a real peak. When necessary, the user can request that the software ignore the first number of shots/peak during ratio computation so as to avoid integrating signals potentially affected by surface common-Pb contamination. Cycles satisfying the conditions de ned by the user (i.e., above the minimum triggering threshold, based on 238U ion signal intensity; and of sufficient channel width) are integrated as part of a multi-shot analysis. Ratios are calculated for a single peak by summing the total number of counts for each isotope across the entire peak width, and applying a subtraction of the baseline average counts (for the same isotope) to this value. A summary of the data handling process for $v .2$ is given in Fig. 1. 


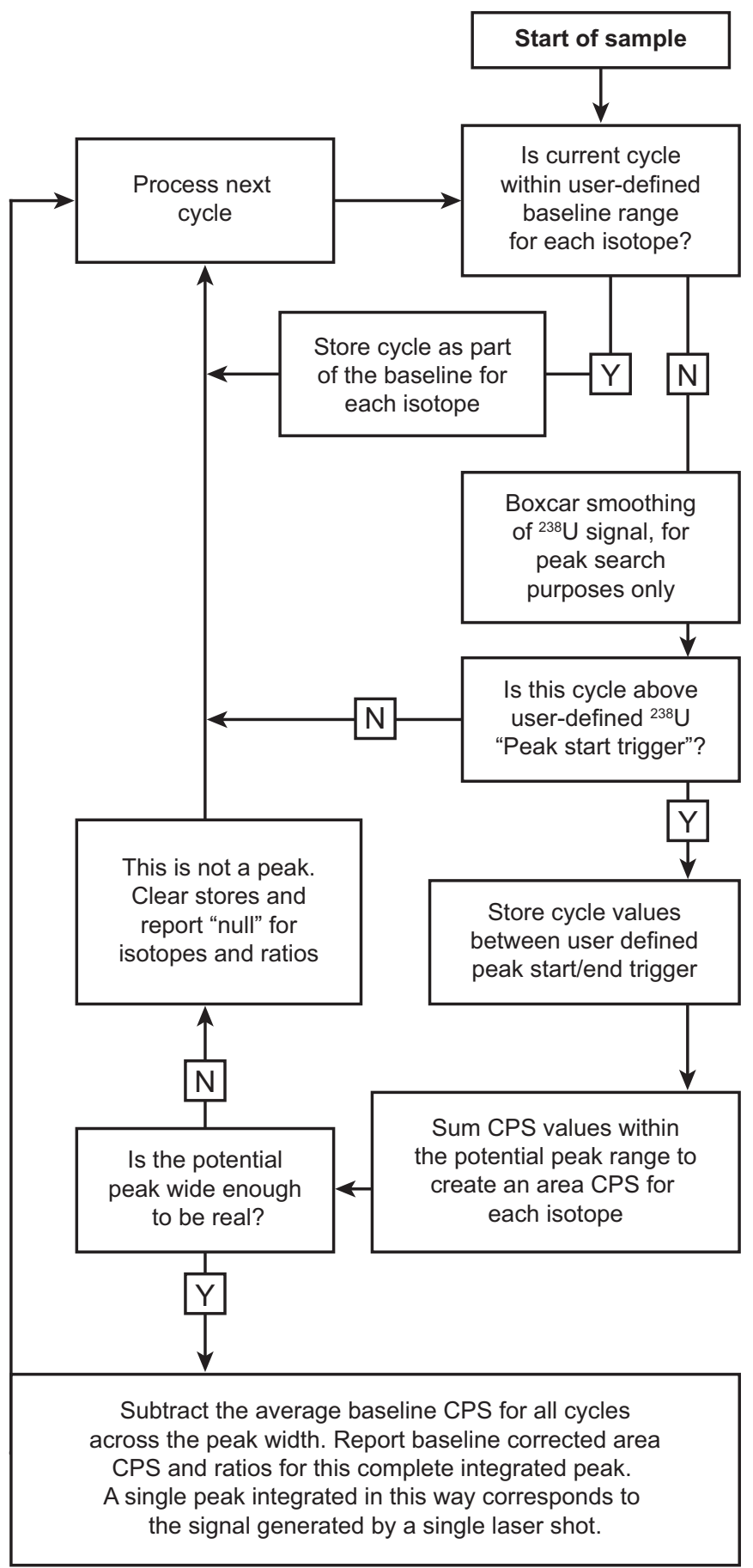

Figure 1. The operational workflow undertaken to crop and integrate 'peak tops' within the NICE script $v .2$.

\subsubsection{Version 5 ( $v .5)$}

Version 5 of the NICE script add-on was used in this study when the cumulative counts on the least abundant isotope measured in a ratio pair (usually ${ }^{207} \mathrm{~Pb}$ ) integrated over the course of an analysis were low (i.e., for analyses of 10 shots and Fish Canyon Tuff (U); see Section 3.4). Version 5 does not operate using a trigger value based on $238 \mathrm{U}$ ion signal intensity to initiate a peak search. Instead the user defines the first and last cycles within a TRA that pertain to an on-peak measurement. Back-to-back peak brackets of a user defined width then divide the space between the first and last peak for an entire TRA. A representative TRA for both NICE script versions are illustrated in Fig. 2. 


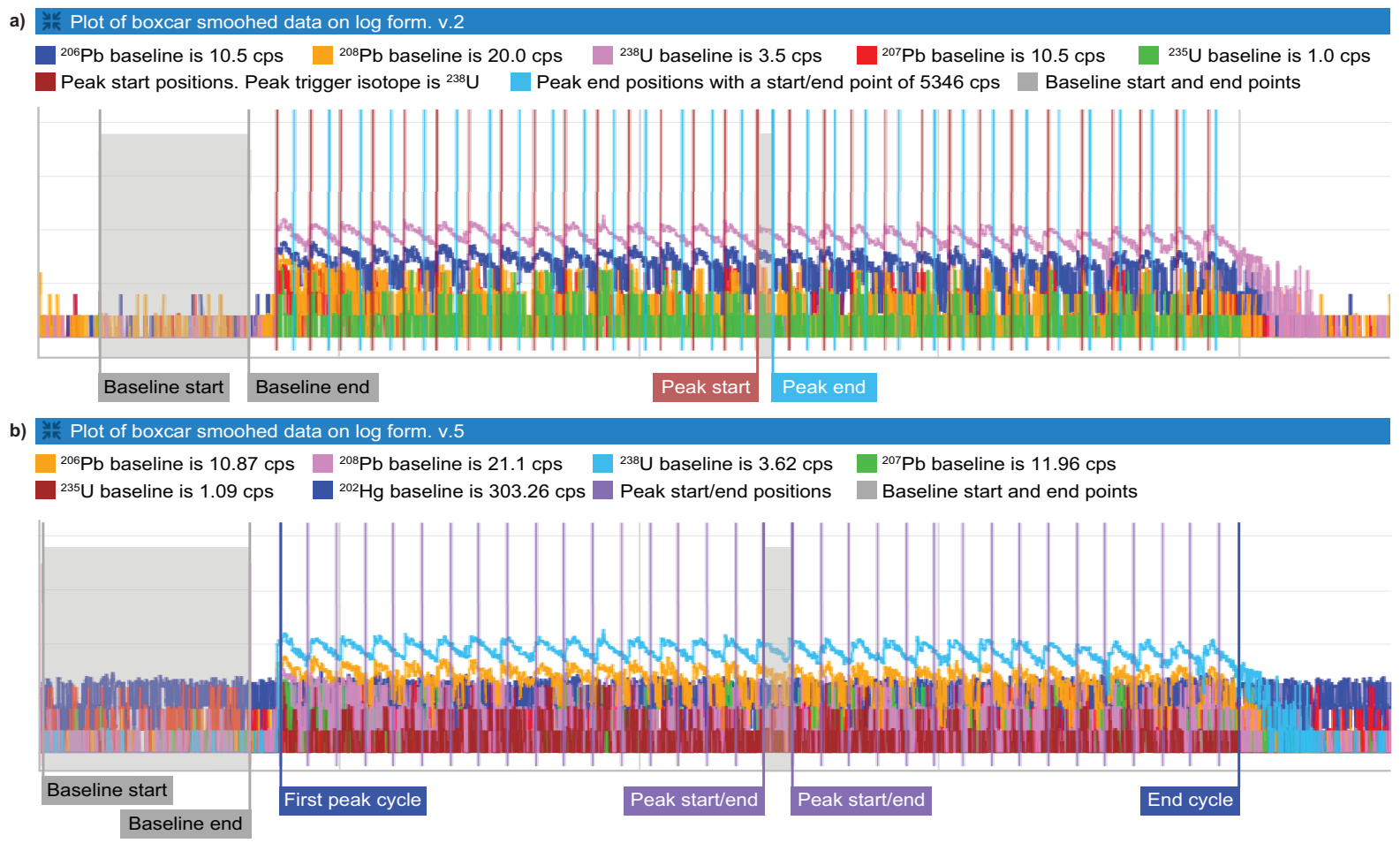

Fig. 2. Representative TRAs as displayed (with annotation) within the Nu-Quant software of both NICE script add-ons for the same 91500 zircon analysis. (a) Version 2 (v.2) was used for data reduction of 30 shot analyses in this contribution, with the exception of Fish Canyon Tuff $(U)$. This version operates by integrating peaks above a threshold 'peak trigger' based on $238 \mathrm{U}$ ion signal intensity for a fixed channel width as defined by the user. This effectively operates to crop peaktops only, ignoring cycles not satisfying user defined thresholds. (b) Version 5 (v.5) was used to integrate analyses of 10 shots and Fish Canyon Tuff $(U)$, where there are fewer cumulative counts to integrate for each isotope. No ion signal intensity dependent peak search function operates in v.5, instead the user defines the first cycle pertaining to the onset of signal pulses and the last. The software then divides the intervening cycles into equal channel widths for integration. The alignment of these fixed width integrations is made difficult with within-run variation in washout efficiency.

\subsection{Linear drift and mass bias correction}

Data processing including correction of instrumental drift and mass bias, as well as uncertainty propagation were carried out using an 'in-house' Microsoft Excel( spreadsheet developed after Simonetti et al. (2005). Mean normalisation factors were calculated for each of the three standard brackets, sensu Fisher et al. (2010). These normalisation factors were multiplied into each integrated ratio for the sample data by fractional degrees, weighted according to their 'within-run' position relative to the standard brackets to correct for instrumental drift and mass bias during the course of an analytical session.

\subsection{Uncertainty propagation and data rejection}

All potential sources of uncertainty were propagated into individual ratio determinations, including those related to the external reproducibility of the primary reference material. No common $\mathrm{Pb}$ or LIEF corrections were applied to data reported here. In all cases ${ }^{207} \mathrm{~Pb} /{ }^{235} \mathrm{U}$ ratios were calculated using the ${ }^{238} \mathrm{U} /{ }^{235} \mathrm{U}$ constant of 137.88 (Steiger and Jäger, 1977) and all ages were calculated using the decay constants of Jaffey et al. (1971). 
Prior to plotting, any acquired data that produced Rho error correlations $>1$ were rejected. For those samples overlapping the Concordia curve, an additional rejection was applied based upon percent discordance, whereby data exceeding user de ned thresholds are excluded (usually data $\geq 20 \%$ discordance are rejected). For those data plotting as discordant arrays, the rejection of data was conducted on a visual basis by the user. All Concordia plots were constructed using IsoplotR (Vermeesch, 2018) and uncertainties therein are reported at the $2 \sigma$ level.

\section{Results}

\subsection{External precision}

Both 91500 (1065.4 $\pm 0.6 \mathrm{Ma}$; Wiedenbeck et al., 1995) and Plešovice (337.13 \pm 0.37 Ma; Sláma et al., 2008) were used as primary reference zircon standards during the course of this study. The reproducibility (2SD\%) of both external reference standards regardless of the pre-treatment they received is $<7.5 \%$ and $<5.5 \%$ for ${ }^{207} \mathrm{~Pb} /{ }^{206} \mathrm{~Pb}$ and ${ }^{206} \mathrm{~Pb} /{ }^{238} \mathrm{U}$, respectively for 30 shot ablations. For analyses employing 10 shots, the reproducibility (2SD\%) of both external reference standards is $<22.5 \%$ and $<5 \%$ ${ }^{207} \mathrm{~Pb} /{ }^{206} \mathrm{~Pb}$ and ${ }^{206} \mathrm{~Pb} /{ }^{238} \mathrm{U}$, respectively. These ratio value determinations were made over the course of several analytical sessions, which were conducted over the course of several days, as summarised in Table 3.

\begin{tabular}{|c|c|c|c|}
\hline $\begin{array}{c}\text { External Reference } \\
\text { Standard }\end{array}$ & $\mathbf{n}$ & $\begin{array}{c}{ }^{207} \mathrm{~Pb} /{ }^{206} \mathrm{~Pb} \\
(2 \mathrm{SD} \%)\end{array}$ & $\begin{array}{c}{ }^{206} \mathrm{~Pb} /{ }^{238} \mathrm{U} \\
(2 \mathrm{SD} \%)\end{array}$ \\
\hline \multicolumn{4}{|c|}{30 shot analyses } \\
\hline $91500(U)$ & $n=80$ & 6.0 & 4.8 \\
\hline $91500(850 / 48)$ & $n=79$ & 6.1 & 4.9 \\
\hline $91500(1100 / 96)$ & $n=49$ & 7.4 & 4.0 \\
\hline Plešovice (U) & $\mathrm{n}=35$ & 6.1 & 3.9 \\
\hline Plešovice $(850 / 48)$ & $n=35$ & 7.2 & 5.4 \\
\hline Plešovice $(1100 / 96)$ & $n=15$ & 5.7 & 1.9 \\
\hline \multicolumn{4}{|c|}{10 shot analyses } \\
\hline $91500(U)$ & $n=55$ & 22.2 & 4.9 \\
\hline Plešovice (U) & $\mathrm{n}=46$ & 16.1 & 4.2 \\
\hline
\end{tabular}

Table 3. External reproducibility ( $2 \mathrm{SD} \%$ ) of baseline subtracted raw ratios achieved for all primary reference standards used within this study.

\subsection{Internal precision}

The internal precision of all measured samples within a given analytical session is summarised in Table 4. The 'within-run' reproducibility (2SD\%) of all samples receiving 30 shots, regardless of the pre-treatment they received is $<2.4 \%$ and $<1.6 \%$ for ${ }^{207} \mathrm{~Pb} /{ }^{206} \mathrm{~Pb}$ and ${ }^{206} \mathrm{~Pb} /{ }^{238} \mathrm{U}$ respectively, with the exception of Fish Canyon Tuff zircon $(\mathrm{U})$. The relatively low abundance of radiogenic $\mathrm{Pb}$ in Fish Canyon Tuff zircon (28.37 $\pm 0.05 \mathrm{Ma}$; Bachmann et al., 2007) reduces the precision achievable for a 30 shot analysis (see Table 4), regardless of the NICE script used to generate integrations. For analyses of 10 shots, the reproducibility (2SD\%) of untreated samples measured is $<3.9 \%$ and $<1.4 \%$ for ${ }^{207} \mathrm{~Pb} /{ }^{206} \mathrm{~Pb}$ and ${ }^{206} \mathrm{~Pb} /{ }^{238} \mathrm{U}$, respectively. These ratio determinations were made during the same analytical sessions for each sample set. Thermal annealing pre-treatment does not improve internal precision. 


\begin{tabular}{lcc}
\multicolumn{1}{c}{ Sample } & $\left.{ }^{207} \mathbf{P b}\right|^{206} \mathbf{P b}(\mathbf{2 S D} \%)$ & $\left.{ }^{206} \mathbf{P b}\right|^{238} \mathbf{U}(\mathbf{2 S D} \%)$ \\
\hline $91500(U)$ & 0.64 & 0.39 \\
$91500(850 / 48)$ & 0.73 & 0.35 \\
$91500(1100 / 96)$ & 0.63 & 0.49 \\
Plešovice (U) & 0.59 & 0.42 \\
Plešovice (850/48) & 0.81 & 0.51 \\
Plešovice (1100/96) & 0.66 & 0.26 \\
DD81-29 (U) & 0.92 & 1.56 \\
DD81-29 (850/48) & 0.34 & 0.64 \\
DD81-29 (1100/96) & 0.31 & 0.84 \\
DD85-17 (U) & 0.68 & 0.98 \\
DD85-17 (850/48) & 0.86 & 1.15 \\
DD85-17 (1100/96) & 0.32 & 0.93 \\
WRS-1348 (U) & 2.35 & 0.86 \\
Fish Canyon Tuff $(U)^{*}$ & 29.41 & 4.83 \\
\hline 91500 (U) & 3.82 & 0.53 \\
Plešovice $(U)^{*}$ & 2.31 & 0.27 \\
WRS-1348 (U) & 3.00 & 1.36
\end{tabular}

Table 4. Internal reproducibility $(2 \mathrm{SD} \%)$ uncorrected ratios achieved $(\mathrm{n}=20)$ for all samples analysed. Those analyses reduced using NICE script v.5 are highlighted with an asterisk $\left(^{*}\right)$

\subsection{Age determinations of validation samples}

The samples utilized to demonstrate the validity of the multi-shot technique outlined herein all have independently verified ID-TIMS ages. All samples regardless of the pre-treatment they received have calculated ages consistently reproducible to within $\leq 1 \%$ of their published age, with the exception of Fish Canyon Tuff (1.34\%). All are within an acceptable range of MSWD values (Spencer et al., 2016). All age plots are included in Fig. 3.

The weighted mean age data (Table 5) regardless of heat treatment applied reproduce to within $<1.57 \%$ of their published U-Pb ID-TIMS ages for analyses of 30 shots. Moreover, most samples typically reproduce to within $\ll 1 \%$ of their published ages. Analyses conducted using 10 shots and reduced using NICE script version 5 (v.5) yield weighted mean ages that are reproducible to within $<0.82 \%$ of their accepted ages on samples of untreated 91500 , Plešovice, and WRS-1348 zircons. All U-Pb results for samples analysed here are displayed both in Concordia diagrams and in weighted mean plots (Fig. 3) demonstrating both the accuracy and precision achieved by the multi-shot LA-ICP-MS approach adopted here. 


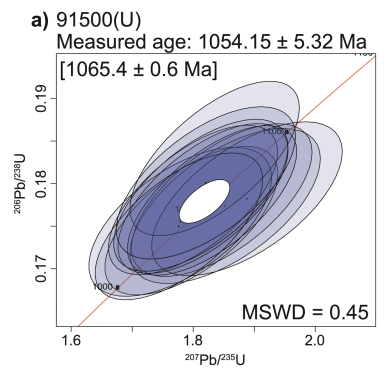

Mean ${ }^{206} \mathrm{~Pb} / 238 \mathrm{U}$ age: $1055.73 \pm 5.73 \mathrm{Ma}$ $[1062.4 \pm 0.4 \mathrm{Ma}] \square \quad \mathrm{MSWD}=0.35$

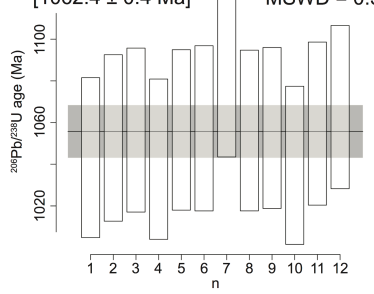

b) $91500-1(U)$

Measured age: $1063.19 \pm 5.04 \mathrm{Ma}$

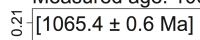

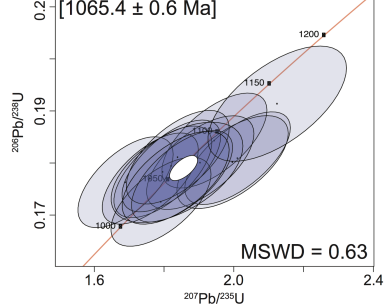

Mean ${ }^{206} \mathrm{~Pb} / 238 \mathrm{U}$ age: $1059.47 \pm 5.52 \mathrm{Ma}$ $[1062.4 \pm 0.4 \mathrm{Ma}]$

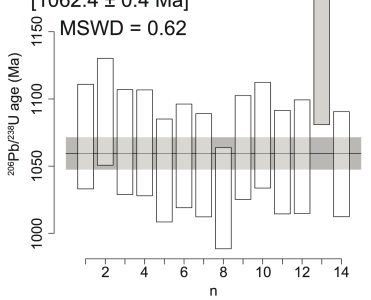

c) $91500-2(U)$

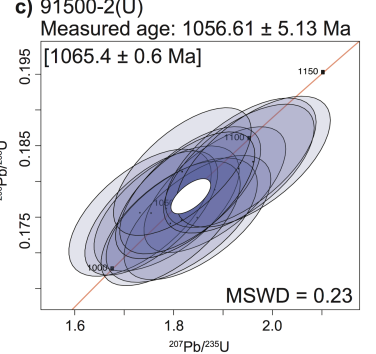

Mean ${ }^{206} \mathrm{~Pb} /{ }^{238} \mathrm{U}$ age: $1056.14 \pm 5.5 \mathrm{Ma}$

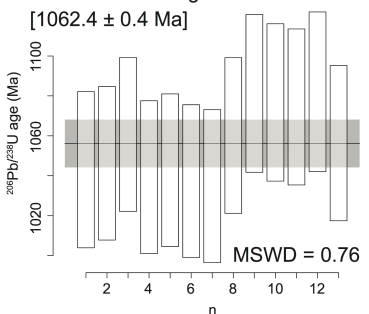

d) $91500(850 / 48)$

Measured age: $1073.79 \pm 5.2 \mathrm{Ma}$ [1065.4 $\pm 0.6 \mathrm{Ma}]$

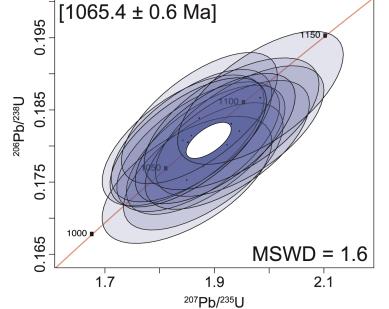

Mean ${ }^{206} \mathrm{~Pb} / 238 \mathrm{U}$ age: $1069.71 \pm 5.76 \mathrm{Ma}$ [1062.4 $\pm 0.4 \mathrm{Ma}$ ] MSWD $=0.49$

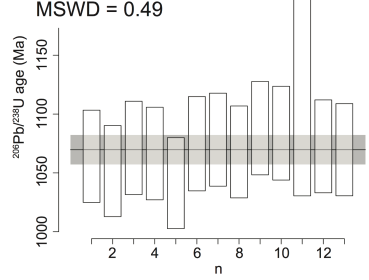

e) $91500(1100 / 96)$

Measured age: $1061.73 \pm 3.13 \mathrm{Ma}$ [ $[1065.4 \pm 0.6 \mathrm{Ma}]$

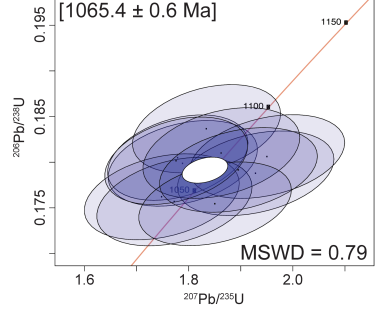

Mean ${ }^{206} \mathrm{~Pb} / 238 \mathrm{U}$ age: $1062.42 \pm 3.18 \mathrm{Ma}$

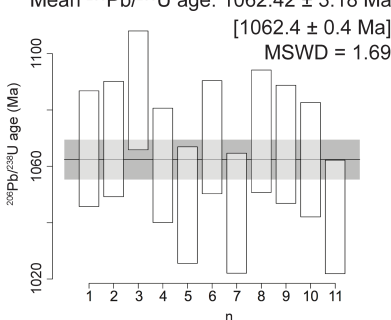

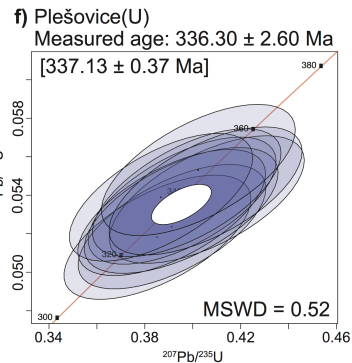

Mean ${ }^{206} \mathrm{~Pb} / 238 \mathrm{U}$ age: $336.15 \pm 2.61 \mathrm{Ma}$

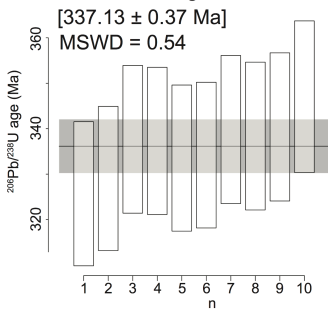

g) Plešovice (850/48)

Measured age: $336.52 \pm 2.59 \mathrm{Ma}$ $[337.13 \pm 0.37 \mathrm{Ma}]$

Mean ${ }^{206} \mathrm{~Pb} / 238 \mathrm{U}$ age: $336.28 \pm 2.61 \mathrm{Ma}$

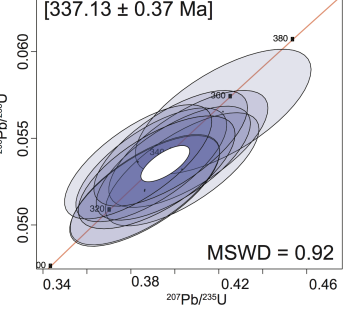
$[337.13 \pm 0.37 \mathrm{Ma}]$

h) Plešovice(1100/96)

Measured age: $334.48 \pm 1.98 \mathrm{Ma} \quad$ Mean ${ }^{206} \mathrm{~Pb} / 238 \mathrm{U}$ age: $334.61 \pm 1.98 \mathrm{Ma}$

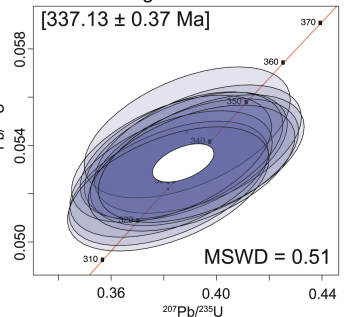

$[337.13 \pm 0.37 \mathrm{Ma}]$

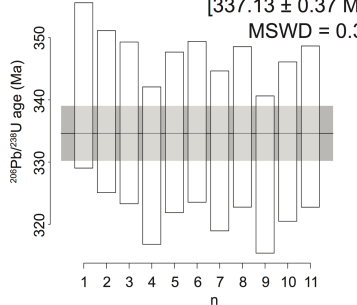

i) WRS-1348(U)

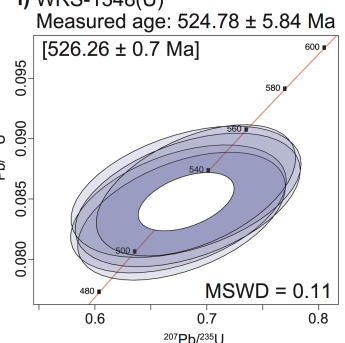

Mean ${ }^{206} \mathrm{~Pb} / 238 \mathrm{U}$ age: $524.57 \pm 5.87 \mathrm{Ma}$ $[526.26 \pm 0.7 \mathrm{Ma}] \quad \mathrm{MSWD}=0.18$

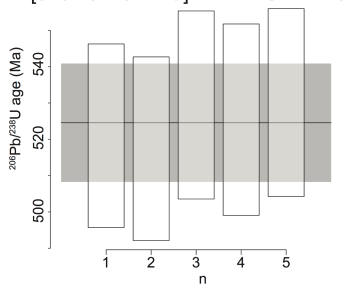

j) Fish Canyon Tuff(U)

Measured age: $27.99 \pm 0.26 \mathrm{Ma}$ o. $[28.37 \pm 0.05 \mathrm{Ma}]$

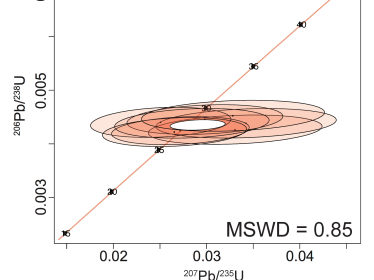

Mean ${ }^{206} \mathrm{~Pb} / 238 \mathrm{U}$ age: $28.01 \pm 0.26 \mathrm{Ma}$ $[28.37 \pm 0.05 \mathrm{Ma}] \quad \mathrm{MSWD}=0.90$

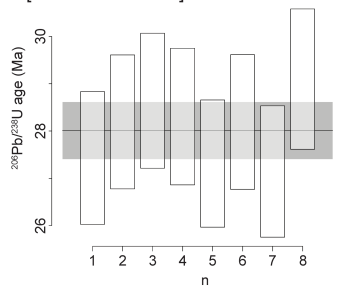



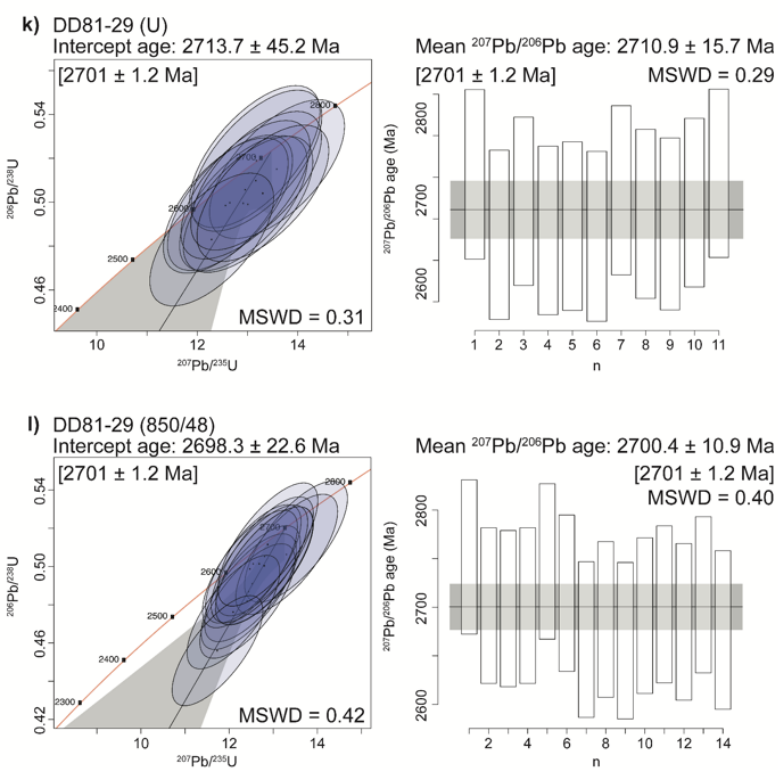

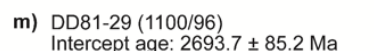
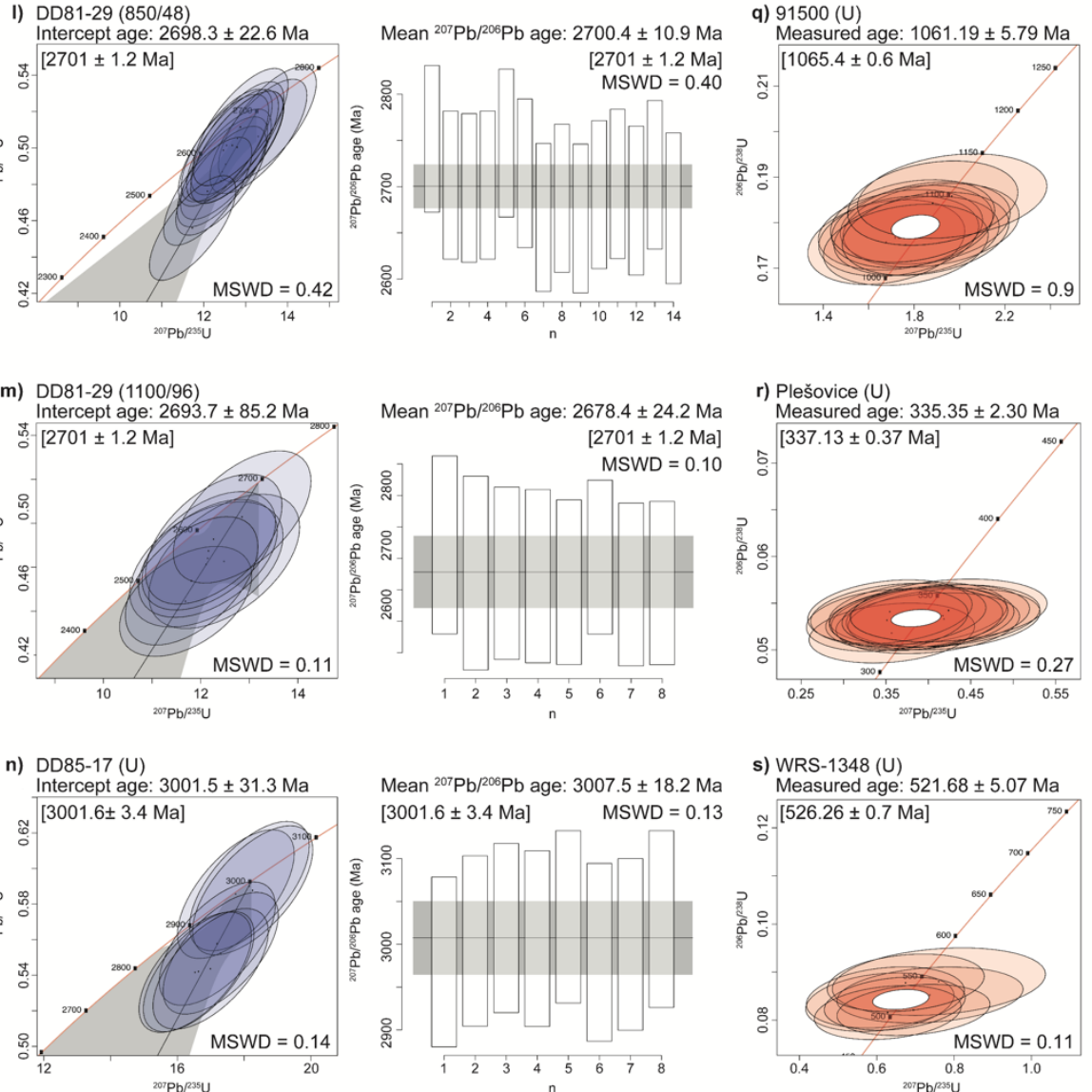

Mean ${ }^{206} \mathrm{~Pb} /{ }^{238} \mathrm{U}$ age: $1062.04 \pm 5.84 \mathrm{Ma}$ $[1062.4 \pm 0.4 \mathrm{Ma}] \quad$ MSWD $=0.73$

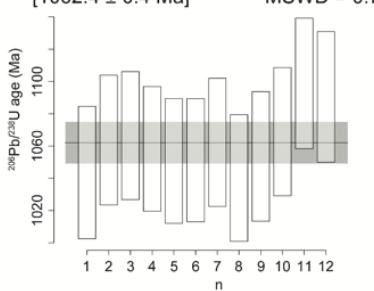

Mean ${ }^{206} \mathrm{~Pb} / 238 \mathrm{U}$ age: $335.46 \pm 2.3 \mathrm{Ma}$ $[337.13 \pm 0.37 \mathrm{Ma}] \quad \mathrm{MSWD}=0.21$
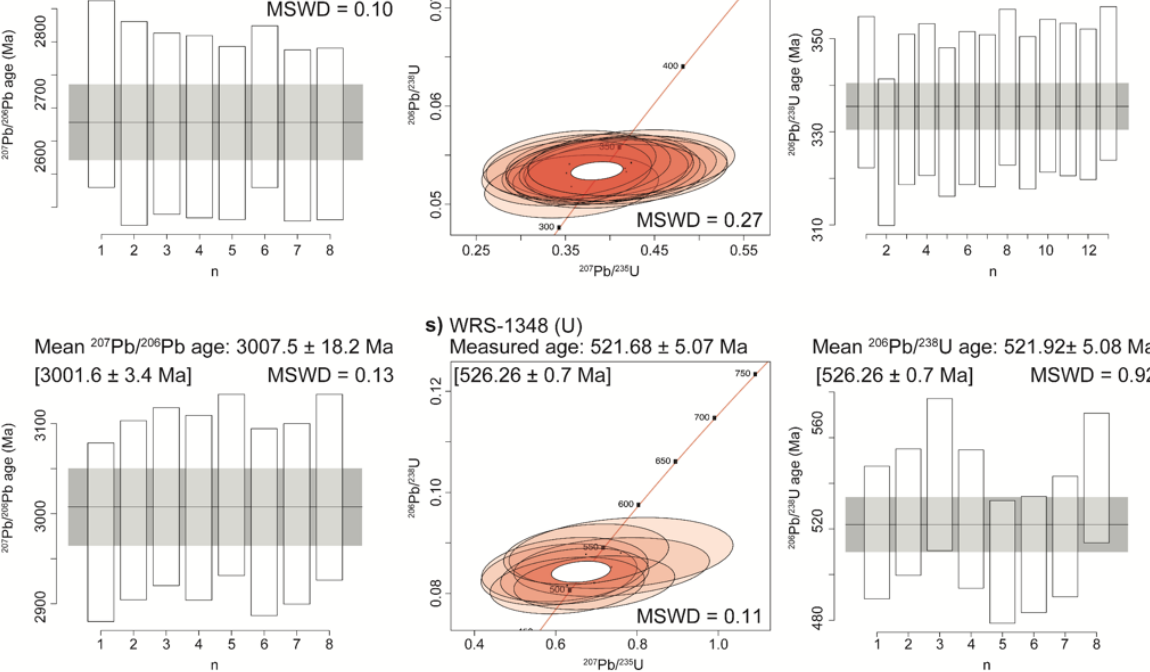

s) WRS-1348 (U)

Measured age: $521.68 \pm 5.07 \mathrm{Ma}$

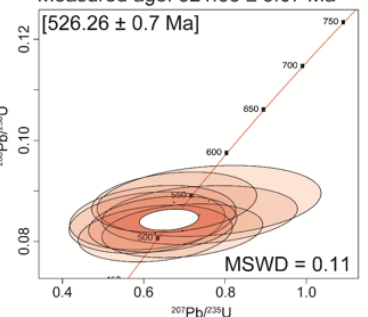

Mean ${ }^{207} \mathrm{~Pb} /{ }^{206} \mathrm{~Pb}$ age: $3048.7 \pm 25.4 \mathrm{Ma}$

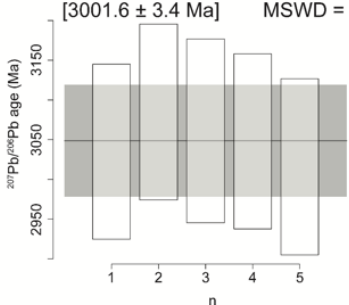$$
\text { . }
$$

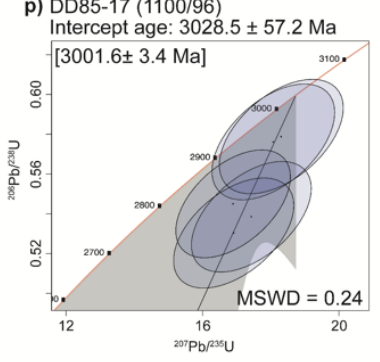


MSWD

n

Weighted
Mean Age

Reproducibility (\%) MSWD

n

NICE

(Ma)

script

\begin{tabular}{|c|c|c|c|c|c|c|c|c|c|}
\hline \multicolumn{10}{|c|}{30 shot analyses } \\
\hline $\begin{array}{l}91500 \\
\text { Wiedenbeck et al., } 1995\end{array}$ & $\begin{array}{r}1065.4 \\
\pm 0.6 \\
\end{array}$ & & & & $\begin{array}{r}1062.4 \pm \\
0.4 \\
\end{array}$ & & & & \\
\hline $91500(\mathrm{U})$ & $\begin{array}{r}1054.15 \\
\pm 5.32\end{array}$ & 1.06 & 0.45 & 12 & $\begin{array}{r}1055.73 \pm \\
5.73\end{array}$ & 0.11 & 0.35 & $12 / 12$ & v.2 \\
\hline $91500-1(U)$ & $\begin{array}{r}1063.19 \\
\pm 5.04\end{array}$ & 0.21 & 0.63 & 14 & $\begin{array}{r}1059.47 \pm \\
5.52\end{array}$ & 0.28 & 0.62 & $13 / 14$ & v.2 \\
\hline $91500-2(U)$ & $\begin{array}{r}1056.61 \\
\pm 5.13\end{array}$ & 0.83 & 0.23 & 13 & $\begin{array}{r}1056.14 \pm \\
5.5\end{array}$ & 0.59 & 0.76 & $13 / 13$ & v.2 \\
\hline $91500(850 / 48)$ & $\begin{array}{r}1073.79 \\
\pm 5.2\end{array}$ & 0.79 & 1.6 & 13 & $\begin{array}{r}1069.71 \pm \\
5.76\end{array}$ & 0.69 & 0.49 & $13 / 13$ & v. 2 \\
\hline $91500(1100 / 96)$ & $\begin{array}{r}1061.73 \\
\pm 2.35\end{array}$ & 0.34 & 0.79 & 11 & $\begin{array}{r}1062.42 \pm \\
3.18\end{array}$ & 0.002 & 1.69 & $11 / 11$ & v.2 \\
\hline $\begin{array}{l}\text { Plešovice } \\
\text { Sláma et al., } 2008\end{array}$ & $\begin{array}{r}337.13 \\
\pm 0.37\end{array}$ & & & & $\begin{array}{r}337.13 \pm \\
0.37\end{array}$ & & & & \\
\hline Plešovice (U) & $\begin{array}{r}336.30 \\
\pm 2.6\end{array}$ & 0.25 & 0.52 & 10 & $\begin{array}{r}336.15 \pm \\
2.61\end{array}$ & 0.29 & 0.54 & $10 / 10$ & v.2 \\
\hline Plešovice (850/48) & $\begin{array}{r}336.52 \\
\pm 2.59\end{array}$ & 0.18 & 0.92 & 10 & $\begin{array}{r}336.28 \pm \\
2.61\end{array}$ & 0.88 & 0.25 & $10 / 10$ & v. 2 \\
\hline Plešovice (1100/96) & $\begin{array}{r}334.48 \pm \\
1.98\end{array}$ & 0.79 & 0.51 & 11 & $\begin{array}{r}334.61 \pm \\
1.98\end{array}$ & 0.75 & 0.37 & $11 / 11$ & v. 2 \\
\hline $\begin{array}{l}\text { DD81-29 } \\
\text { Davis \& Edwards, } 1986\end{array}$ & $\begin{array}{r}2701 \pm \\
1.2\end{array}$ & & & & $\begin{array}{r}2701 \pm \\
1.2\end{array}$ & & & & \\
\hline DD81-29 (U) & $\begin{array}{r}2713.7 \\
\pm 45.2\end{array}$ & 0.47 & 0.31 & 11 & $\begin{array}{r}2710.9 \pm \\
15.7\end{array}$ & 0.37 & 0.29 & $11 / 11$ & v.2 \\
\hline DD81-29 (850/48) & $\begin{array}{r}2698.3 \\
\pm 22.6\end{array}$ & 0.10 & 0.42 & 14 & $\begin{array}{r}2700.4 \pm \\
10.9\end{array}$ & 0.02 & 0.40 & $14 / 14$ & v. 2 \\
\hline DD81-29 (1100/96) & $\begin{array}{r}2693.7 \\
\pm 85.2\end{array}$ & 0.27 & 0.11 & 8 & $\begin{array}{r}2678.4 \pm \\
24.2\end{array}$ & 0.84 & 0.10 & $8 / 8$ & v. 2 \\
\hline $\begin{array}{l}\text { DD85-17 } \\
\text { Tomlinson et al., } 2003\end{array}$ & $\begin{array}{r}3001.6 \\
\pm 3.4\end{array}$ & & & & $\begin{array}{r}3001.6 \pm \\
3.4\end{array}$ & & & & \\
\hline DD85-17 (U) & $\begin{array}{r}3001.5 \\
\pm 31.3\end{array}$ & 0.003 & 0.14 & 8 & $\begin{array}{r}3007.5 \pm \\
18.2\end{array}$ & 0.20 & 0.13 & $8 / 8$ & v.2 \\
\hline
\end{tabular}




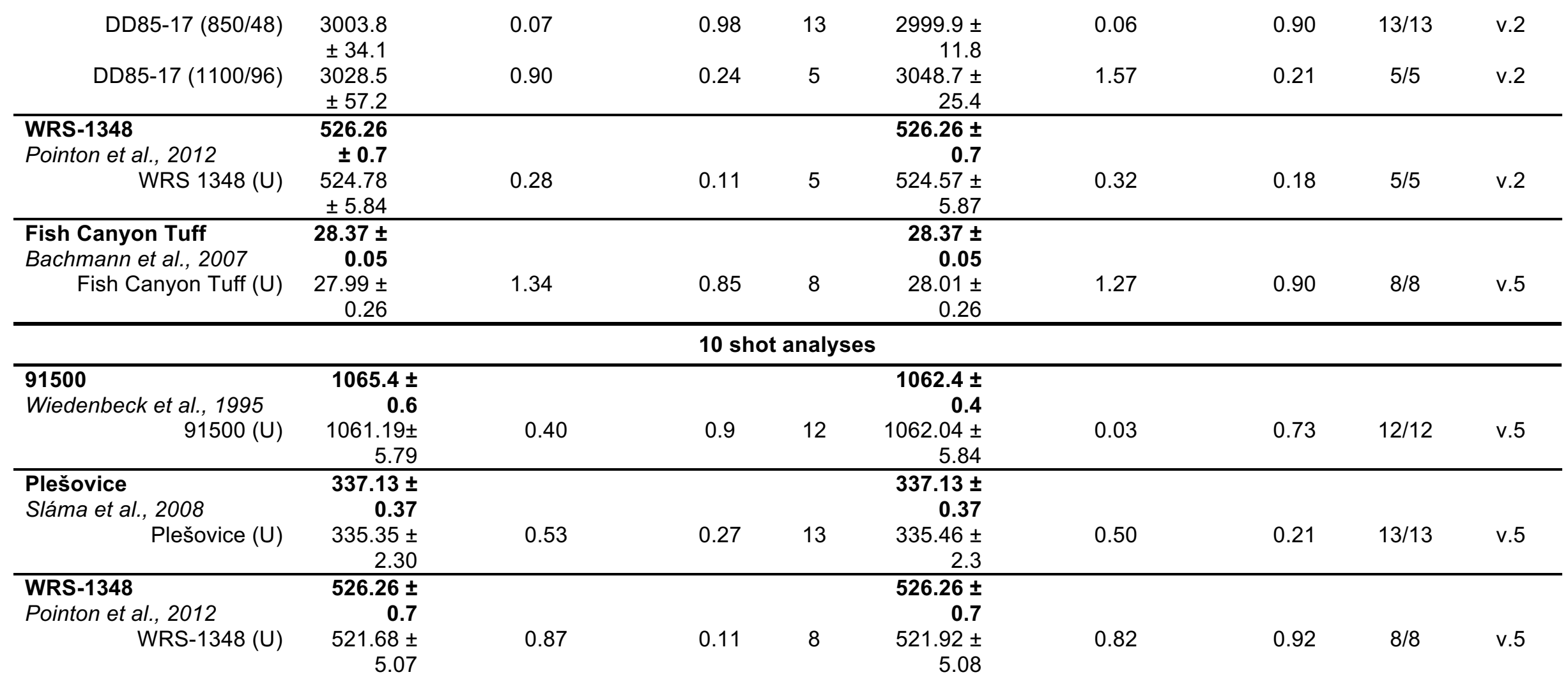


Table 5. Summary of age data illustrated in Fig. 3. Accepted ages for each sample are highlighted in bold. 91500 zircon was used as the primary reference standard for all analyses with the exception of those 91500 samples where Plešovice was used instead. Weighted mean ages are based on ${ }^{206} \mathrm{~Pb} /{ }^{238} \mathrm{U}$ ratios for zircons younger than $1100 \mathrm{Ma}$, otherwise the mean ${ }^{207} \mathrm{~Pb} /{ }^{206} \mathrm{~Pb}$ age is adopted for reference.

\subsection{NICE script comparison}

Signal integration by either NICE data reduction script will be inhibited when the least abundant isotope measured in a ratio pair (i.e., ${ }^{207} \mathrm{~Pb}$ ) fails to exceed (or remains close to) the LOQ. Fish Canyon Tuff (U) zircon has a relatively low abundance of radiogenic $\mathrm{Pb}$ (i.e. $<5$ ppm; Bachmann et al., 2007), and is therefore ideally suited when comparing the efficacy of both NICE script v. 2 and v.5 for samples and/ or shot counts yielding lower signal intensities.

A 30 shot analysis of Fish Canyon Tuff $(U)$ was processed in the first instance using NICE script v.2, which operates to sub-sample integrations (described in detail in Section 2.4.1). This effective 'peak-top' cropping reduces the counts integrated for each laser pulse for each isotope, consequently ${ }^{207} \mathrm{~Pb}$ ion signals are for the most part below the LOQ. When plotted in Tera-Wasserberg space (Fig. 4a), calculated U/Pb ratios display apparent "Pb gain" effects and/or interferences on mass 204 . The ion signal for mass 204 remains below LOQ for both NICE script versions however. Consequently, surface contamination by common $\mathrm{Pb}$ cannot be invoked to explain the apparent "Pb gain" observed when reducing the data using NICE script v.2. Instead, this effect is wholly artificial, being an artefact of poor counting statistics on mass 207.

NICE script v.5 by contrast integrates the entirety of a signal pulse. By processing a TRA with the latter script, the resultant counts for a given laser pulse exceed the LOQ for mass 207 and consequently ${ }^{206} \mathrm{~Pb} /{ }^{238} \mathrm{U}$ and ${ }^{207} \mathrm{~Pb} /{ }^{235} \mathrm{U}$ remain unaffected by poor counting statistics (Fig. 4b). This highlights the utility of NICE script v.5 when low ion signals are recorded for either for young zircons, such as Fish Canyon Tuff and/or for analyses of $<30$ shots.

Analyses conducted using a shot count of 10 also encountered problems associated with low $\mathrm{Pb}$ ion signals where data reduction was con- ducted in the 'peak-top' cropping fashion of the NICE script v.2. Thus, for these analyses NICE script v.5 was used instead. Analyses of 10 shots reduced in this way reproduce to within $<0.87 \%$ of their accepted concordia ages based on analyses of untreated 91500 , Plešovice, and WRS-1348. More accurate weighted mean ages result from reducing the entirety of a peak as with NICE script v.5 for analyses yielding low signal counts; however, external reproducibility suffers as a result (see Table 3 ). NICE script v.2. should be utilised preferentially when analysing samples either with a high abundance of $\mathrm{Pb}$ or when using a shot count $>10$. 


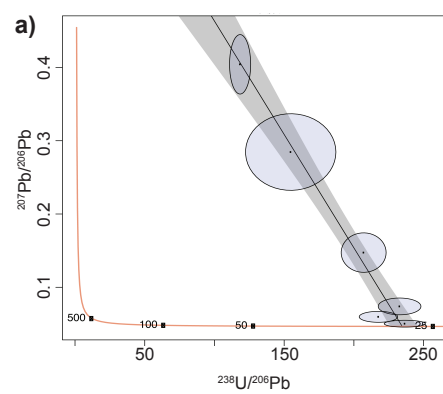

Fish Canyon Tuff (U)

NICE script Version 2 (v.2)

Measured age: $27.42 \pm 0.41 \mathrm{Ma}$

Accepted age: $27.52 \pm 0.09 \mathrm{Ma}$

MSWD: $1.6 \mathrm{n}=6$

Reproducibility: $0.98 \%$

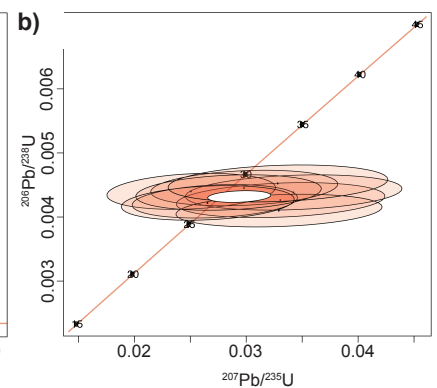

NICE script Version 5 (v.5)

Measured age: $27.78 \pm 0.24 \mathrm{Ma}$ Accepted age: $27.52 \pm 0.09 \mathrm{Ma}$ MSWD: $2.1 \mathrm{n}=9$

Reproducibility: 0.94\%

Figure 4. A comparison of age data generated for the same 30 shot analysis of Fish Canyon Tuff (U) zircon using (a) NuQuant NICE script v. 2 plotted in Tera-Wasserberg space and (b) NICE script v. 5 plotted in Wetherill Concordia space. Uncertainties are quoted at a $2 \sigma$ level with a confidence interval of $95 \%$. Plots were generated using IsoplotR (Vermeesch, 2018).

\subsection{Monitoring time-dependent fractionation}

The degree of time-dependent 'downhole' fractionation occurring during a single laser ablation analysis is determined by monitoring the variability of the measured ${ }^{206} \mathrm{~Pb} /{ }^{238} \mathrm{U}$ ratio on a shot-to-shot basis. Where time-dependent fractionation of ${ }^{206} \mathrm{~Pb}$ over a relatively more refractory ${ }^{238} \mathrm{U}$ has occurred during ablation, an increasing trend in measured ${ }^{206} \mathrm{~Pb} /{ }^{238} \mathrm{U}$ would be expected on a shot-to-shot basis as the ablation crater deepens. Calculating the degree of time-dependent fractionation over the course of an analysis can be made by dividing the mean ${ }^{206} \mathrm{~Pb} /{ }^{238} \mathrm{U}$ ratio of the first half of an analysis by its corresponding second segment. This calculation constitutes a fractionation index (FI). A FI of near unity suggests a minimal degree of timedependent fractionation has occurred over the course of an analysis. Fig. 5 charts the variability of the ${ }^{206} \mathrm{~Pb} /{ }^{238} \mathrm{U}$ ratio on a shot-to-shot basis over the course of various representative analyses of both 30 and 10 shots (Fig. 5. a and b, respectively). No discernible trend of increase exists for ${ }^{206} \mathrm{~Pb} /{ }^{238} \mathrm{U}$ measured between shots over the course of an individual analysis and all have a FI near unity, suggesting minimal timedependent 'downhole' fractionation has occurred. 

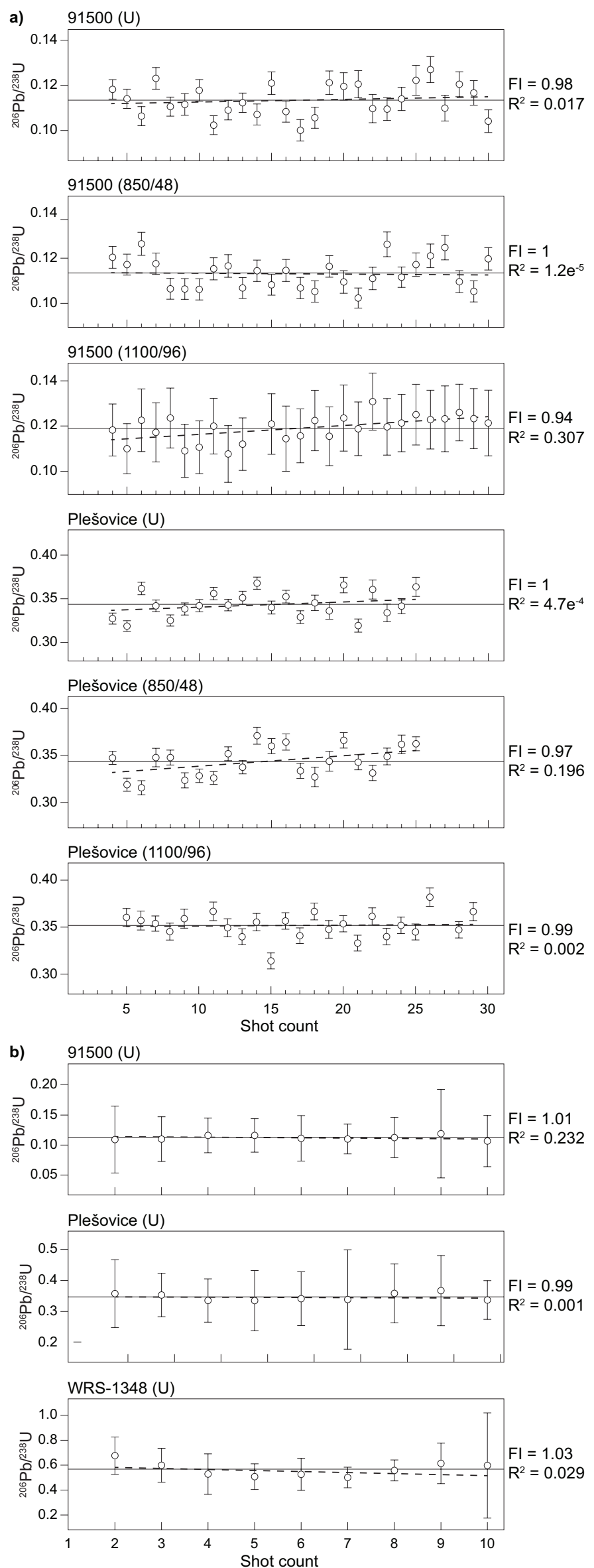
Figure $5 .{ }^{206} \mathrm{~Pb} /{ }^{238} \mathrm{U}$ variability charted on a shot-to-shot basis for representative analyses of both; (a) 30 and; (b) 10 shots. Examples of heat-treated samples are also shown. Ratio uncertainties are calculated based upon the minimum ${ }^{206} \mathrm{~Pb}$ counts received for each individual shot. Little to no ratio variability in the above analyses results in a $\mathrm{FI}$ of near unity for each, suggesting timedependent 'downhole' fractionation has been significantly reduced for crater aspect ratios $<<1$.

\subsection{Sample volume estimates}

Individual crater depth measurements and their associated uncertainties are derived from repeated cross-sectional transects $(n=5)$ of the pit diameter viewed using WLI. Mean crater depth, depth variability and mean ablated volume estimates are summarised in Table 6 for each sample set $(n=20)$. Estimates for the ablated volume assumes a cylindrical crater geometry and $100 \%$ transport efficiency of the analyte to the ICP source (i.e., no sample re-deposition or loss within the transfer line to the ICP). The calculated depth achieved per laser pulse is between $47 \mathrm{~nm}$ and $70 \mathrm{~nm}$, depending on the target sample.

Fig. $6 a$ and $b$ are based a representative WLI analysis of Plešovice (U), with a crosssection comparison of 30 and 10-shot craters. Small-scale inhomogeneous sampling at the crater floor is evidenced in Fig. 6a, which is exaggerated in its vertical dimension. The al- ternate plan view offered by Fig. 6b, demonstrates the lateral extent of this sampling inhomogeneity. The effect is less pronounced for 10-shot craters.

A qualitative comparison of laser matter interaction is shown by secondary electron images. Fig. $6 c$ and c' illustrates a crater produced by static high frequency ablation ( $5 \mathrm{~Hz}, 20 \mathrm{~s}$ ), with all other parameters being maintained as they are for the multi-shot approach

described herein. It has been included as a point of comparison between craters produced by 30 and 10-shots (Fig. 6d-d' and e-e', respectively) in the same target matrix (i.e., a single fragment of $91500(U)$ ). The relative depth, degree of welding and re-deposition is clearly reduced (albeit not eliminated) where fewer shots are applied. The 1:1 scaling of secondary electron imaging also emphasises the much-reduced aspect ratio of craters produced by the multi-shot approach adopted in this study. 


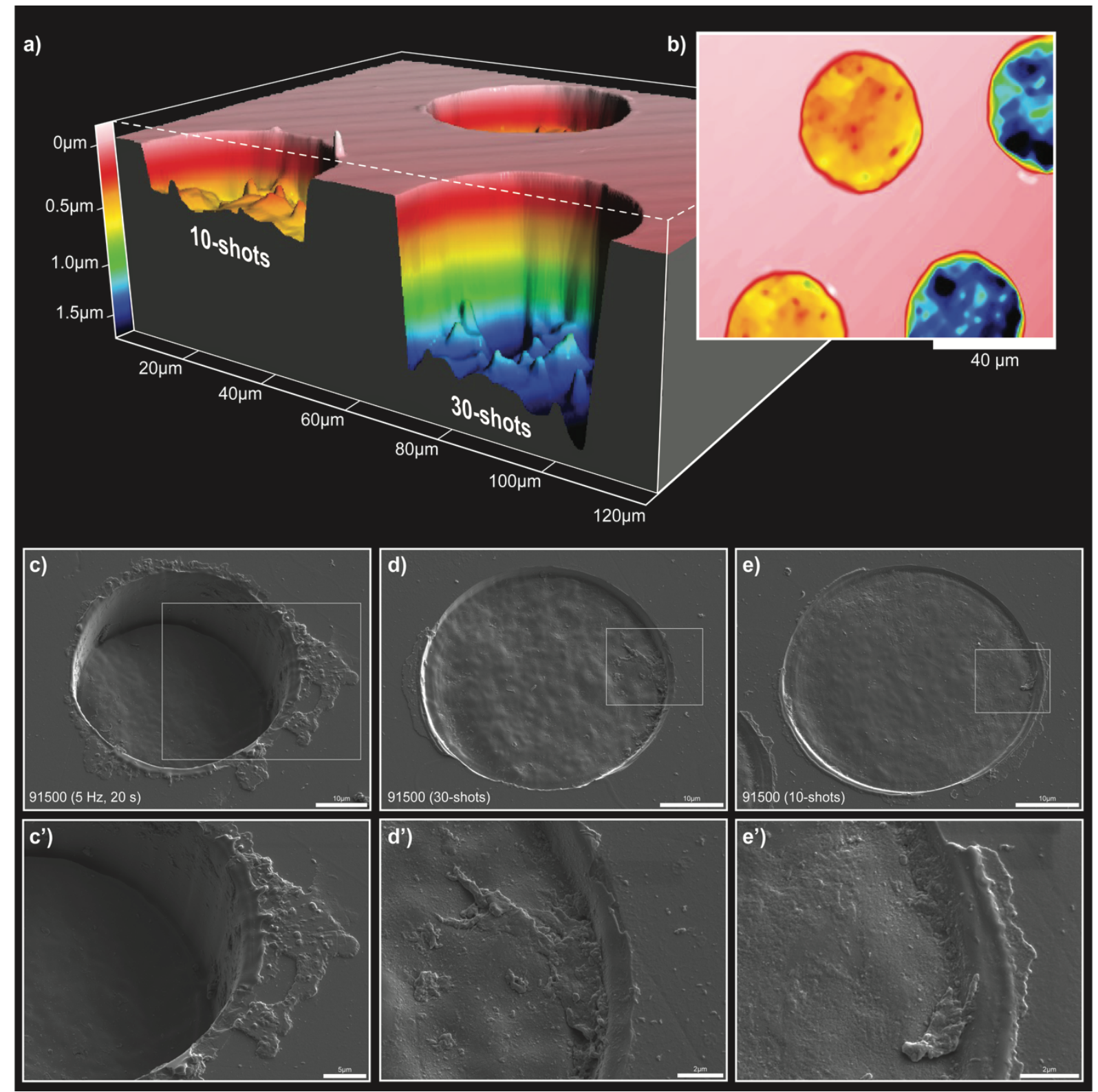

Figure 6. (a) A 3-dimensional rendering of the crater morphologies resulting from 30 and 10 shot analyses of Plešovice $(U)$ measured by WLI. It should be noted that the vertical scaling of this graphic is exaggerated. (b) A top-down view of the same Plešovice $(U)$ sample surface. This view evidences inhomogeneous sampling at the crater floor. (c-c') Secondary electron SEM images of a static high frequency ablation (5 Hz, $20 \mathrm{~s}$ ) conducted on $91500(\mathrm{U})$, where all other analytical parameters are maintained as employed for multi-shot analysis. Evidence of significant welding and analyte re-deposition is present. The white box in (c) represents the magnified view of the redeposited material presented in (c'). (d-d') Secondary electron SEM images of a crater generated by 30 consecutive shots on the same fragment of 91500 . The crater aspect ratio, as well as the degree of melt generation and re-deposition are significantly reduced relative to that observed in (c) and (c'). (e-e') Secondary electron SEM images of a crater generated by 10 consecutive shots on the same fragment of 91500 . The crater aspect ratio, as well as the degree of melt generation and re-deposition are again comparatively reduced to that observed in the high frequency static ablation (c-c').

\subsection{Thermal annealing}

Marillo-Sialer et al. (2016) demonstrated that the rate of ablation of a zircon matrix is at least partially controlled by the crystalline order of its lattice. Thermal annealing was investigated as a means by which to exercise some degree of control over ablation 
rate (depth) of the target matrix and the geometry of the resultant craters. The WLI data (summarised in Table 6) demonstrate little utility of thermal annealing as a pretreatment in limiting resultant crater depths following multi-shot ablation. The variable behaviour of crater excavation was assessed by calculating the standard deviation of the resultant crater depths for a given sample set. The variability (2SD\%) of crater depths for any given sample set is $<31.2 \%$. Thermally annealed sample sets demonstrated no discernible improvement in variability (2SD\%) over their untreated counterparts.

Despite reproducing predominantly to within $1 \%$ of their accepted mean ages, the ages calculated for thermally annealed samples often did not overlap (within uncertainty) of their accepted ages. This variability in accuracy would remain difficult to assess for unknowns treated by annealing and analysed by the multi-shot LA-ICPMS method described here. The most accurate age determinations were made on untreated samples having (for the most part) delivered larger volumes of analyte to the ICP-MS instrument. 


\begin{tabular}{|c|c|c|c|c|c|c|c|}
\hline Sample Name & $\begin{array}{c}\text { Mean } \\
\text { Crater } \\
\text { Depth }(\mu \mathrm{m})\end{array}$ & $\begin{array}{c}\text { Crater Aspect } \\
\text { Ratio } \\
\text { (depth/diameter) }\end{array}$ & $\begin{array}{c}\text { Crater } \\
\text { Depth } \\
\text { Variability } \\
(2 S D \%)\end{array}$ & $\begin{array}{c}\text { Approx. } \\
\text { Depth } \\
\text { per } \\
\text { Shot } \\
(\mu \mathrm{m}) \\
\end{array}$ & $\begin{array}{l}\text { Mean Ablated } \\
\text { Volume }\left(\mu \mathrm{m}^{3}\right)\end{array}$ & $\begin{array}{c}\text { Approx. } \\
\text { Zircon } \\
\text { consumption } \\
(\mathbf{n g})^{*}\end{array}$ & $\begin{array}{c}\text { Approx. Pb } \\
\text { consumption }(p g)^{* *}\end{array}$ \\
\hline \multicolumn{8}{|c|}{30 shot analyses } \\
\hline $91500(U)$ & $1.41 \pm 0.03$ & 0.04 & 13.2 & 0.05 & $1770 \pm 120$ & 8.24 & $0.11-0.13$ \\
\hline 91500 (850/48) & $1.53 \pm 0.06$ & 0.04 & 19.8 & 0.05 & $1930 \pm 240$ & 8.97 & $0.12-0.14$ \\
\hline $91500(1100 / 96)$ & $1.90 \pm 0.07$ & 0.05 & 22.5 & 0.06 & $2390 \pm 360$ & 11.10 & $0.14-0.18$ \\
\hline Plešovice (U) & $1.67 \pm 0.10$ & 0.04 & 31.2 & 0.06 & $2100 \pm 420$ & 9.77 & $0.21-1.54$ \\
\hline Plešovice (850/48) & $1.82 \pm 0.06$ & 0.05 & 16.8 & 0.06 & $2290 \pm 270$ & 10.65 & $0.22-1.68$ \\
\hline Plešovice (1100/96) & $1.79 \pm 0.07$ & 0.04 & 20.6 & 0.06 & $2250 \pm 310$ & 10.46 & $0.22-1.65$ \\
\hline DD81-29 (U) & $2.11 \pm 0.08$ & 0.05 & 18.7 & 0.07 & $2650 \pm 450$ & 12.32 & - \\
\hline DD81-29 (850/48) & $1.98 \pm 0.09$ & 0.05 & 17.9 & 0.07 & $2490 \pm 430$ & 11.58 & - \\
\hline DD81-29 (1100/96) & $1.51 \pm 0.06$ & 0.04 & 19.5 & 0.05 & $1900 \pm 240$ & 8.84 & - \\
\hline DD85-17 (U) & $1.57 \pm 0.07$ & 0.04 & 24.1 & 0.05 & $1970 \pm 290$ & 9.16 & - \\
\hline DD85-17 (850/48) & $1.67 \pm 0.10$ & 0.04 & 29.3 & 0.06 & $2100 \pm 410$ & 9.77 & - \\
\hline DD85-17 (1100/96) & $1.62 \pm 0.07$ & 0.04 & 23.7 & 0.05 & $2040 \pm 300$ & 9.49 & - \\
\hline Fish Canyon Tuff $(U)$ & $1.65 \pm 0.08$ & 0.04 & 24.0 & 0.06 & $2080 \pm 330$ & 9.67 & $0.01-0.05$ \\
\hline \multicolumn{8}{|c|}{10 shot analyses } \\
\hline $91500(U)$ & $0.56 \pm 0.02$ & 0.01 & 15.0 & 0.02 & $704 \pm 23$ & 3.27 & $0.04-0.05$ \\
\hline Plešovice (U) & $0.62 \pm 0.01$ & 0.02 & 8.6 & 0.02 & $779 \pm 17$ & 3.60 & $0.08-0.57$ \\
\hline WRS-1348 (U) & $0.70 \pm 0.02$ & 0.02 & 15.5 & 0.02 & $880 \pm 35$ & 4.09 & $0.02-0.04$ \\
\hline
\end{tabular}

Table 6. Data summary of crater morphology and ablation behaviour for several heat treated and untreated zircon matrixes. Mean crater depths $(\mathrm{n}=$ 20 ) as measured by WLI and include analyses of both 30 and 10 shots. *Assuming the specific gravity of zircon to be $4.65 \mathrm{~g} \mathrm{~cm}-3$ (Deer et al., 1992 ) ${ }^{* *} \mathrm{~Pb}$ concentrations used for approximation are derived from (1) Wiedenbeck et al., 1995; (2) Sláma et al., 2008; (3) Pointon et al., 2012; (4) Bachmann et al., 2007. 


\section{Discussion}

\subsection{Accuracy and Precision}

The accuracy of the multi-shot LA-ICP-MS analytical method re-ported here is typically within the $1-2 \%(2 \sigma)$ level expected for conventional static LA-ICP-MS analysis (Horstwood et al., 2016). The least abundant isotope measured in a ratio pair (i.e., ${ }^{207} \mathrm{~Pb}$ in $\mathrm{U}$-(Th)-Pb geochronology) will remain the limiting factor for determining the accuracy and precision of this technique. Consequently, accuracy and precision are inextricably linked to the volume of analyte produced, and therefore both can only be improved at the expense of depth or lateral resolution.

\subsection{Thermal annealing as a pre-treatment}

Slight variations in optical and thermo-physical properties between zircon matrices due to either radiation damage-induced lattice defects and/or colour will affect the laser-zircon interaction, and thus the amount of material removed by each laser pulse (Kooijman et al., 2012; Marillo-Sialer et al., 2014). Several previous studies have shown that the rate of ablation of a zircon matrix is at least partially controlled by the order of its crystalline lattice (Allen and Campbell, 2012; Crowley et al., 2014; MarilloSialer et al., 2016). The magnitude to which zircon crystal lattice recovery by annealing exhibits control over ablation behaviour was examined over 30 shots in this study.

There is only partial support for the hypothesis put forward by Allen and Campbell (2012) that increasing crystal density via annealing reduces the rate ablation rate of the target analyte. In this study, annealed sample sets almost all demonstrate an increased mean crater depth relative to that of their untreated counterpart, with the notable exception of DD81-29. A reduction in ablation rate therefore, cannot be invoked as a universal behavioural response of annealed zircon matrices. There is also little evidence to suggest that annealing as a pre-treatment unifies/homogenises the ablation response of a sample set to incident laser radiation at the spatial scale investigated here. No discernible improvement in crater depth variability for annealed sample sets is observed, again with the exception of DD81-29. The effect of annealing on both crater geometries and/or resulting ages is difficult to assess between sample sets and is therefore not necessary as a pre-treatment for the protocol described herein.

\subsection{Applications in geochronology}

Where natural minerals are concerned, structural and chemical in- homogeneities are often present yet unresolvable using conventional LA-ICP-MS approaches. By integrating and collating multiple, consecutive single shots it is possible to generate precise ages, which are statistically indistinguishable from dates determined by IDTIMS. Collating multiple signal pulses in this manner allows for an age determination to be made for as few as 10 shots. Depending on the number of shots applied to the target material, vertical sampling can be conducted from the micron to the sub-micron scale. The ion signals recorded for the least abundant isotope measured (i.e., ${ }^{207} \mathrm{~Pb}$ ) will remain the limiting factor for vertical resolution of this approach. The laser protocol outlined in this study was designed to be generally applicable to zircon U-Pb work, employing practicable spot sizes and moderate laser fluences. Modifications to this protocol could potentially be employed to maximise ion signals for fewer shots (and hence improve the vertical spatial resolution), alternatively an increased number of shots may be applied to improve the analytical accuracy and precision of the technique 
described here, so long as a critical aspect ratio of $<1$ is maintained in order to minimise LIEF.

\section{Conclusions}

A multi-shot approach to U-Pb age determinations by LA-ICP-MS al- lows for precise and often indistinguishable ages compared to those determined by ID-TIMS for the same zircon reference materials and unknowns. The instrumental set-up requires no modification of the standard equipment for both the UP213 laser ablation system and Attom HR-ICP-MS employed here. Moreover, the standard ablation cell allows for the maintenance of elevated signal intensities when utilised in con- junction with a short washout interval between shots. The shallow ablation depths achieved by multi-shot analysis allow for precise age de- terminations to be made both on the micron to submicron scale whilst negating the need to apply a 'downhole' inter-elemental fractionation correction.

\section{Acknowledgments}

This work was funded by a Naughton Foundation Fellowship from the University of Notre Dame (USA) to A. Simonetti and Q. Crowley, and a Trinity Award from Trinity College Dublin (Ireland) to E. Corbett. Donald Davis is thanked for providing zircon samples DD81-29 and DD85-17. David Chew is thanked for providing zircon sample WRS-1348 and for providing helpful discussion on the manuscript. Leona O'Connor is thanked for her assistance with the WLI instrument. Paul Guyett is thanked for his assistance in collecting the SEM images. The anonymous reviewers are also thanked for their constructive comments, which helped improve the manuscript.

\section{Appendix}

An annotated copy of the NICE script v.2 has been included as a python formatted text le in the online version of this article. Working copies of the NICE scripts described herein can be acquired from the associated online data repository or by contacting Nu.attomservice@ ametek.com directly. Supplementary data to this article can be found online.

\section{References}

Allen, C M, Campbell, I H, 2012. Identification and elimination of a matrix-induced systematic error in LA-ICP-MS ${ }^{206} \mathrm{~Pb} /{ }^{238} \mathrm{U}$ dating of zircon. Chem. Geol. 332-333, 157-165. doi:10.1016/j.chemgeo.2012.09.038.40.39

Bachmann, O, Oberli, F, Dungan, M A, Meier, M, Mundil, R, Fischer, H, 2007. Ar/ Ar and $\mathrm{U}-\mathrm{Pb}$ dating of the Fish Canyon magmatic system, San Juan Volcanic field, Colorado: evidence for an extended crystallization history. Chem. Geol. 236, 134-166. doi:10.1016/j.chemgeo.2006.09.005.

Bleiner, D, Günther, D, 2001. Theoretical description and experimental observation of aerosol transport processes in laser ablation inductively coupled plasma mass spectrometry. J. Anal. At. Spectrom. 16 (5), 449-456. doi:10.1039/B009729m.

Chew, D, Drost, K, Petrus, J, 2018. Ultrafast, > 50 Hz LA-ICP-MS spot analysis applied 
to U-Pb dating of zircon and other U-bearing minerals. Geostand. Geoanal. Res. 43, 39-60. doi:10.1111/ggr.12257.

Cottle, J M, Horstwood, M S A, Parrish, R R, 2009. A new approach to single shot laser ablation analysis and its application to in situ $\mathrm{Pb} / \mathrm{U}$ geochronology. J. Anal. At. Spectrom. 24, 1355-1363. doi:10.1039/b821899d.

Cottle, J M, Kylander-Clark, A R, Vrijmoed, J C, 2012. U-Th/Pb geochronology of detrital zircon and monazite by single shot laser ablation inductively coupled plasma mass spectrometry (SS-LA-ICPMS). Chem. Geol. 332-333, 136-147. doi:10.1016/ j.chemgeo.2012.09.035.

Crowley, Q G, Heron, K, Riggs, N, Kamber, B S, Chew, D, McConnell, B, Benn, K, 2014. Chemical abrasion applied to LA-ICP-MS U-Pb zircon geochronology. Minerals 4, 503-518. doi:10.3390/min4020503.

Davis, D W, Edwards, G R, 1986. Crustal evolution of Archean rocks in the Kakagi Lake area, Wabigoon subprovince, Ontario, as interpreted from high-precision U-Pb geochronology. Can. J. Earth Sci. 23, 182-192. doi:10.1139/e86-021.

Deer, W A, Howie, R A, Zussman, J, 1992. An Introduction to the Rock-Forming Minerals. 2nd ed. Longman, London, UK, p. 1992.

Eggins, S M, Kinsley, L P J, Shelley, J M G, 1998. Deposition and element fractionation processes during atmospheric pressure laser sampling for analysis by ICP-MS. Appl. Surf. Sci. 127-129, 278-286. doi:10.1016/S0169-4332(97)00643-0.

Fernández, Beatriz, Claverie, Fanny, Pécheyran, Christophe, Donard, Olivier, 2007. Trends in Analytical Chemistry 26 (10), 951-966. doi:10.1016/j.trac.2007.08.008. https:// doi.org/10.1016/j.trac.2007.08.008.

Fisher, C F, Longerich, H P, Jackson, S E, Hanchar, J M, 2010. Data acquisition and calculation of $\mathrm{U}-\mathrm{Pb}$ isotopic analyses using laser ablation (single collector) inductively coupled plasma mass spectrometry. J. Anal. At. Spectrom. 25 (12), 1905-1920. doi:10.1039/C004955G.

Fryer, B J, Jackson, S E, Longerich, H P, 1995. Design, operation and role of the Laser-Ablation Microprobe Coupled with an Inductively-Coupled Plasma Mass Spectrometer (LAM-ICP-MS) in the Earth-Sciences. Can. Mineral. 33 (2), 303-312. doi:10.1016/0009-2541(93)90058-Q.

Guillong, M, Günther, D, 2002. E ect of particle size distribution on ICP-induced elemental fractionation in laser ablation-inductively coupled plasma-mass spectrometry. J. Anal. At. Spectrom. 17 (8), 831-837. doi:10.1039/B202988J.

Günther, D, Heinrich, C A, 1999. Enhanced sensitivity in laser ablation-ICP mass spectrometry using helium-argon mixtures as aerosol carrier. J. Anal. At. Spectrom. 14, 1363-1368. doi:10.1039/A901648A.

Hirata, T, Nesbitt, R W, 1995. U-Pb isotope geochronology and zircon: evaluation of the laser probe-inductively coupled plasma mass spectrometry technique. Geochim. Cosmochim. Acta 59, 2491-2500. doi:10.1016/0016-7037(95)00144-1. 
Horn, I, Günther, D, 2003. The in uence of ablation carrier gasses $\mathrm{Ar}, \mathrm{He}$ and $\mathrm{Ne}$ on the particle size distribution and transport e ciencies of laser ablation-induced aerosols: implications for LA-ICP-MS. Appl. Surf. Sci. 207, 144-157. doi:10.1016/ S0169-4332(02)01324-7.

Horn, I, Rudnick, R L, McDonagh, W F, 2000. Precise elemental and isotope ratio determination by simultaneous solution nebulization and laser ablation-ICP-MS: application to U-Pb geochronology. Chem. Geol. 164 (3-4), 281-301. doi:10.1016/ S0009-2541(99)00168-0.

Horstwood, M S A, 2008. Data reduction strategies, uncertainty assessment and resolution of LA-(MC-)ICP-MS isotope data. In: Sylvester, P (Ed.), Laser Ablation ICPMS in the Earth Sciences: Current Practices and Outstanding Issues. In: Mineral. Assoc. Can. pp. 283-303 (Short course, 40, 40). http://nora.nerc.ac.uk/id/eprint/5731/.

Horstwood, M S A, Košler, J, Gehrels, G, Jackson, S E, McLean, N M, Paton, C, Pearson, N J, Sircombe, K N, Sylvester, P, Vermeesch, P, Bowring, J F, Condon, D $\mathrm{J}$, Schoene, B, 2016. Community-derived standards for LA-ICP-MS U-(Th-)Pb geochronology - uncertainty propagation, age interpretation and data reporting. Geostand. Geoanal. Res. 40, 311-332. doi:10.1111/j.1751-908X.2016.00379.x.

Jackson, S E, Pearson, N J, Gri n, W L, Belousova, E, 2004. The application of laser ablation-inductively coupled plasma-mass spectrometry to in situ $\mathrm{U}-\mathrm{Pb}$ zircon geochronology. Chem. Geol. 211 (1-2), 47-69. doi:10.1016/j.chemgeo.2004.06.017.

Jaffey, A H, Flynn, K F, Glendenin, L E, Bentley, W C, Essling, A M, 1971. Precision measurement of half-lives and specific activities of $235 \mathrm{U}$ and $238 \mathrm{U}$. Phys. Rev. Series C4, 1889-1905. doi:10.1103/PhysRevC.4.1889.

Koch, J, Feldmann, I, Jakubowski, N, Niemax, K, 2002. Elemental composition of laser ablation aerosol particles deposited in the transport tube to an ICP. Spectrochim. Acta Part B. 57, 975-985. doi:10.1016/S0584-8547(02)00021-6.

Kooijman, E, Berndt, J, Mezger, K, 2012. U-Pb dating of zircon by laser ablation ICPMS: recent improvements and new insights. Eur. J. Mineral. 24, 5-21. doi:10.1127/ 0935-1221/2012/0024-2170.

Košler, J, Wiedenbeck, M, Wirth, R, Hovorka, J, Sylvester, P, Míková, J, 2005. Chemical and phase composition of particles produced by laser ablation of silicate glass and zircon - Implication for elemental fractionation during ICP-MS analysis. J. Anal. At. Spectrom. 20 (5), 402-409. doi:10.1039/b416269b.

Košler, J, Sláma, J, Belousova, E, Corfu, F, Gehrels, G E, Gerdes, A, Horstwood, M S A, Sircombe, K N, Sylvester, P, Tiepolo, M, Whitehouse, M J, Woodhead, J D, 2013. $\mathrm{U}-\mathrm{Pb}$ detrital zircon analysis - results of an inter-laboratory comparison. Geostand. Geoanal. Res. 37, 243-259. doi:10.1111/j.1751-908X.2013.00245.x.

Kroslakova, I, Günther, D, 2007. Elemental fractionation in laser ablation- inductively coupled plasma-mass spectrometry: evidence for mass load induced matrix effects in the ICP during ablation of a silicate glass. J. Anal. At. Spectrom. 22, 51-62. doi:10.1039/B606522H. 
Kuhn, H R, Guillong, M, Günther, D, 2004. Size-related vaporisation and ionisation of laser-induced glass particles in the inductively coupled plasma. Anal. Bioanal. Chem. 378 (4), 1069-1074. doi:10.1007/s00216-003-2346-7.

Kuhn, B K, Birbaum, K, Luo, Y, Günther, D, 2009. Fundamental studies on the ablation behaviour of $\mathrm{Pb} / \mathrm{U}$ in NIST 610 and zircon 91500 using laser ablation inductively coupled plasma mass spectrometry with respect to geochronology. J. Anal. At. Spectrom. 25, 21-25. doi:10.1039/B917261K.

Liu, H, Borisov, O, Mao, X, Shuttleworth, S, Russo, R, 2000. Pb/U Fractionation during $\mathrm{Nd}$ :YAG $213 \mathrm{~nm}$ and $266 \mathrm{~nm}$ Laser Ablation Sampling with Inductively coupled Plasma Mass Spectrometry. Appl. Spectrosc. 54 (10), 1435-1442.

Longerich, H P, Jackson, S E, Günther, D, 1996. Inter-laboratory note. Laser ablation inductively coupled plasma mass spectrometric transient signal data acquisition and analyte concentration calculation. J. Anal. At. Spectrom. 11 (9), 899-904. doi:10.1039/JA9961100899.

Mank, A J G, Mason, P R D, 1999. A critical assessment of laser ablation ICP-MS as an analytical tool for depth analysis in silica-based glass samples. J. Anal. At. Spectrom. 14 (8), 1143-1153. doi:10.1039/A903304A.

Mank, A J G, Mason, P R D, 2001. Depth-resolved analysis in multi-layered glass and metal materials using laser ablation inductively coupled plasma mass spectrometry (LA-ICP-MS). J. Anal. At. Spectrom. 16, 1381-1388. doi:10.1039/B106932B.

Marillo-Sialer, E, Woodhead, J D, Hergt, J, Grieg, A, Guillong, M, Gleadow, A, Evans, N, Paton, C, 2014. The zircon "matrix e ect": evidence for an ablation rate control on the accuracy of U-Pb age determinations by LA-ICP-MS. J. Anal. At. Spectrom. 29 (6), 981. doi:10.1039/c4ja00008k.

Marillo-Sialer, E, Woodhead, J D, Hanchar, J M, Reddy, S M, Greig, A, Hergt, J, Kohn, $B, 2016$. An investigation of the laser-induced zircon matrix effect. Chem. Geol. 438, 11-24. doi:10.1016/j.chemgeo.2016.05.014.

Mattinson, J, 2005. Zircon U-Pb chemical abrasion (bCA-TIMSQ) method: combined annealing and multi-step partial dissolution analysis for improved precision and accuracy of zircon ages. Chem. Geol. 220, 47-66. doi:10.1016/ j.chemgeo.2005.03.011.

Nasdala, L, Kronz, A, Hanchar, J M, Tichomirowa, M, Davis, D W, Hofmeister, W, 2006. E ects of natural radiation damage on back-scattered images of single crystals of minerals. Am. Mineral. 91, 1739-1746. doi:10.2138/am.2006.2241.

Pointon, M A, Cli , R A, Chew, D M, 2012. The provenance of Western Irish Namurian Basin sedimentary strata inferred using detrital zircon U-Pb LA-ICP-MS geochronology. Geol. J. 47, 77-98. doi:10.1002/gj.1335.

Russo, R E, Mao, X L, Borisov, O V, Liu, H, 2000. In uence of wavelength on fractionation in laser ablation ICP-MS. J. Anal. At. Spectrom. 15, 1115-1120. doi:10.1039/ B004243I. 
Shaheen, M E, Gagnon, J E, Fryer, B J, 2012. Femtosecond (fs) lasers coupled with modern ICP-MS instruments provide new and improved potential for in situ elemental and isotopic analyses in the geosciences. Chem. Geol. 330-331, 260-273. doi:10.1016/ j.chemgeo.2012.09.016.

Simonetti, A, Heaman, L M, Hartlaub, R P, Creaser, R A, MacHattie, T G, Böhm, C, 2005. U-Pb zircon dating by laser ablation-MC-ICP-MS using a new multiple ion counting Faraday collector array. J. Anal. At. Spectrom. 20, 677-686. doi:10.1039/b504465k.

Sláma, J, Košler, J, Condon, D J, Crowley, J L, Gerdes, A, Hanchar, J M, Horstwood, M S A, Morris, G A, Nasdala, L, Norberg, N, Schaltegger, U, Schoene, B, Tubrett, M $\mathrm{N}$, Whitehouse, $\mathrm{M} \mathrm{J}$, 2008. Plešovice zircon-a new natural reference material for U$\mathrm{Pb}$ and $\mathrm{Hf}$ isotopic microanalysis. Chem. Geol. 249, 1-35. doi:10.1016/ j.chemgeo.2007.11.005.

Spencer, C J, Kirkland, C L, Taylor, R J M, 2016. Strategies towards statistically robust interpretations of in situ U-Pb zircon geochronology. Geosci. Front. 7, 581-589. doi:10.1016/j.gsf.2015.11.006.

Steiger, R H, Jäger, E, 1977. Subcommission on geochronology: Convention on the use of decay constants in geo- and cosmochronology. Earth Planet. Sci. Lett. 36, 359362. doi:10.1016/0012-821X(77)90060-7.

Tomlinson, K Y, Davis, D W, Stone, D, Hart, T R, 2003. U-Pb Age and Nd Isotopic Evidence for Archean Terrane Development and Crustal Recycling in the SouthCentral Wabigoon Subprovince, Canada. 144. pp. 684-702. doi:10.1007/s00410-0020423-0.

Vermeesch, P, 2018. IsoplotR: a free and open toolbox for geochronology. Geosci. Front. 9, 1479-1493. doi:10.1016/j.gsf.2018.04.001.

Wiedenbeck, M, Allé, P, Corfu, F, Gri n, W L, Meier, M, Oberli, F, von Quadt, A, Roddick, J C, Spiegel, W, 1995. Three natural zircon standards for U-Th-Pb, Lu-Hf, trace element and REE analyses. Geostand. Newslett. 19, 1-23. doi:10.1111/ j.1751908X.1995.tb00147.x.

Woodhead, J D, Hergt, J M, 2001. Strontium, neodymium and lead isotope analyses of NIST glass certi ed reference materials: SRM 610,612, 614. Geostand. Newslett. 25 (2-3), 261-266. doi:10.1111/j.1751-908X.2001.tb00601.x. 